\title{
Palaeolithic artefact deposits at Wadi Dabsa, Saudi Arabia; a multi-scalar geoarchaeological approach to building an interpretative framework.
}

\section{Preprint version}

Robyn H. Inglis

robyn.inglis@york.ac.uk

Department of Archaeology, University of York, York, UK

Department of Environmental Sciences, Macquarie University, Sydney, Australia

Patricia C. Fanning

Department of Environmental Sciences, Macquarie University, Sydney, Australia

Abi Stone

Department of Geography, University of Manchester, UK

Dan N. Barfod

Scottish Universities Environmental Research Centre, East Kilbride, Glasgow, UK

Anthony Sinclair

Department of Archaeology, Classics and Egyptology, University of Liverpool

Hsing-Chung Chang

Department of Environmental Sciences, Macquarie University, Sydney, Australia

Abdullah M. Alsharekh

Department of Archaeology, King Saud University, Riyadh, Saudi Arabia

Geoff Bailey

Department of Archaeology, University of York, York, UK

Department of Archaeology, Flinders University, Adelaide, Australia 


\begin{abstract}
Surface artefacts dominate the archaeological record of arid landscapes, particularly the Saharo-Arabian belt, a pivotal region in dispersals out of Africa. Discarded by hominins, these artefacts are key to understanding past landscape use and dispersals, yet behavioural interpretation of present-day artefact distributions cannot be carried out without understanding how geomorphological processes have controlled, and continue to control, artefact preservation, exposure and visibility at multiple scales.

We employ a geoarchaeological approach to unravelling the formation of a surface assemblage of 2,970 Early and Middle Stone Age lithic artefacts at Wadi Dabsa, Saudi Arabia, the richest locality recorded to date in the southwestern Red Sea coastal region. Wadi Dabsa basin, within the volcanic Harrat Al Birk, contains extensive tufa deposits formed during wetter conditions. We employ regional landscape mapping and automatic classification of surface conditions using satellite imagery, field observations, local landform mapping, archaeological survey, excavation, and sedimentological analyses to develop a multi-scalar model of landscape evolution and geomorphological controls acting on artefact distributions in the basin. The main artefact assemblage is identified as a palimpsest of activity, actively forming on a deflating surface, a model with significant implications for future study and interpretation of this, and other, artefact surface assemblages.
\end{abstract}

KEY WORDS: Landscape Archaeology; Palaeolithic; Geomorphology; Saudi Arabia; Geoarchaeology; Remote Sensing. 


\section{INTRODUCTION}

Surface accumulations of lithic artefacts are key archaeological archives for understanding patterns of mobility and landscape use by past hunter-gatherer populations (see, for example: Holdaway \& Douglass, 2012; Holdaway, Douglass, \& Fanning, 2012; Holdaway \& Fanning, 2014; Davies, Holdaway, \& Fanning, 2016, In Press). While surface assemblages may lack the tight chronological constraints provided by sealed archaeological remains, the patterning of artefacts across a landscape is the legacy of a suite of activities that resulted in the discard of artefacts. This patterning therefore has the potential to retain signatures of past hunter-gatherer landscape use recorded on a spatial scale beyond that possible from single site excavations (Foley \& Lahr, 2015; Jennings et al., 2015). Examination of surface artefact distributions within their landscape context, and in particular consideration of locations where large numbers of artefacts are observed, opens the possibility of using these artefacts and assemblages to understand how past populations interacted with their landscapes. Understanding the patterning of surface assemblages may inform us about the ways in which landscape features such as water or raw material sources and topography may have influenced mobility and activity within a landscape, and thus the mechanisms and conditions of dispersals (Finlayson, 2013; Devès, Sturdy, Godet, King, \& Bailey, 2014; Holdaway, King, Douglass, \& Fanning, 2015; Winder et al., 2015; Breeze et al., 2016;).

The archaeological record of the Saharo-Arabian belt was formed by hominin populations dispersing within and out of Africa and is therefore the key to understanding such dispersals (Foley \& Lahr, 1997; Rose, 2007; van Peer \& Vermeersch, 2007; Barham \& Mitchell, 2008; Drake, Blench, Armitage, Bristow, \& White, 2011; Drake, Breeze \& Parker, 2013; Garcea, 2012, 2016; Groucutt et al., 2015). The arid and semi-arid regions of Arabia contain an abundance of surface artefacts that might be typologically assigned to dispersing groups of Homo erectus and later H. sapiens populations (Potts, Mughannum, Frye, \& Sanders, 1978; Zarins, Ibrahim, Potts \& Edens, 1979; Zarins, Whalen, Ibrahim, Morad \& Khan 1980; Ingraham, Johnson, Rihani, \& Shatla, 1981; Zarins, Murad \& Al-Yaish, 1981; Zarins, Rahbini \& Kamal, 1982; Petraglia, 2003; Petraglia \& Alsharekh, 2003; Rose \& Petraglia, 2009; Petraglia, Haslam, Fuller, Boivin, \& Clarkson, 2010; Armitage et al., 2011; Rose et al., 2011; Delagnes et al., 2012; Bailey et al., 2013; Inglis et al., 2014; Groucutt et al., 2018). The surface artefact record of Arabia provides a potential opportunity to examine behavioural, cognitive and technological change, and its implications for dispersals out of Africa, if effectively interpreted. 
Due to its proximity to the Indian Ocean Monsoon and the orographic rainfall generated by the Arabian Escarpment (Rosenberg et al., 2012), the south-eastern Red Sea littoral region was a potential refuge during periods of aridity across the Saharo-Arabian belt (Bailey, 2009; Parker, 2009; Jennings et al., 2015). It contains a rich archaeological record covering potentially 1.8 million years (Zarins et al. 1980, 1982; Inglis et al., 2014; Bailey et al., 2015; Foulds et al., 2017). The discovery of a dense accumulation of almost 3,000 Early Stone Age (ESA) and Middle Stone Age (MSA) artefacts associated with extensive tufa deposits at Wadi Dabsa in the volcanic Harrat al Birk, Asir Province (Inglis et al., 2015, 2017; Foulds et al., 2017) represents the richest Palaeolithic locality recorded to date in southwestern Saudi Arabia (Sinclair et al., In Press), offering a rare chance to examine ESA and MSA activity at different scales within a landscape that may have proved persistently attractive to hominins over an extended period of time. Research questions at Wadi Dabsa focus on examining the archaeological assemblage in its landscape context. Does the location of the artefacts mark a particular concentration of hominin activity, perhaps attracted by the intersection of factors such as accessible raw material, access to water and prey animals, and good views across the basin? Under what environmental and landscape conditions did this activity take place? Did the landscape, and therefore the opportunities it afforded, change during the period of hominin occupation in the region? How does our understanding of hominin dispersals change in response to the answers to these questions?

Interpretation of landscape use and hominin behaviour from surface artefact distributions across a modern landscape is not a straightforward matter of mapping artefact densities. Firstly, landscapes are dynamic in space and time, and landscape features and environmental conditions that may have attracted past populations, such as lakes or sources of raw material, may have disappeared and reappeared multiple times; we therefore need to reconstruct the history of these features to understand when and where these conditions existed. Secondly, as well as shaping the resources available to past populations, the geomorphological evolution of the landscape shapes, at all spatial scales, where artefacts are preserved, exposed and rendered visible to survey, processes which continue to impact the record today (Fanning \& Holdaway, 2004; Fanning, Holdaway, \& Rhodes, 2007). To develop interpretations of the surface archaeological record, we must therefore first understand its geomorphic context, and to what extent artefact patterning, at all scales, may be a product of geomorphological processes rather than behavioural ones (Holdaway \& Fanning, 2008; Knight \& Zerboni, 2018). Thirdly, the artefacts which are observed cannot be interpreted as an ethnographic snapshot of the past 
(Stern, 1994); nearly all archaeological deposits are palimpsests of repeated activities, and thus represent varying time envelopes (Bailey, 2007; Stern, 2008) which may, in the case of Palaeolithic surface artefact assemblages, encompass tens or even hundreds of thousands of years.

This paper considers the dynamic landscape and geomorphic context of the Wadi Dabsa assemblage, the processes shaping its formation, and their implications for the future analysis and interpretation of this important assemblage. At the basin-scale, it presents a model of landscape and environmental evolution to be tested and constrained by future chronometric dating. It constructs a framework for understanding the geomorphological processes shaping the distribution of surface artefacts across the basin, and the implications of this framework for interpretation of the observed artefact distribution at the basin scale. It examines the processes controlling the dense accumulation of surface artefacts observed at one specific location within the Wadi Dabsa basin, and the extent to which the formation history of this assemblage can link the artefacts to the landscape stratigraphy, and to constrain the time depth of the assemblage, laying the foundations for future detailed analysis of one of the richest localities recorded to date in southwestern Saudi Arabia.

\section{STUDY AREA: THE HARRAT AL BIRK}

The Harrat Al Birk, SW Saudi Arabia, is one of several harrat (volcanic fields) across the Arabian Shield (Coleman, Gregory, \& Brown 1983). Spanning the area between the present-day Red Sea coastline and the foothills of the Arabian Escarpment, between N18.76$17.79^{\circ}$ latitude, it is a major (over $1,800 \mathrm{~km}^{2}$ ) and distinct geomorphological zone that interrupts the flat Tihamat Asir coastal plain bordering the Red Sea (Figure 1; Vincent, 2008). The Harrat al Birk comprises extensive basaltic flows, volcanic deposits, and cinder cones formed by repeated eruptions. The dates for eruptions are poorly-constrained but estimates using K-Ar whole rock dating range from 0.2 to 2.6Ma (Coleman et al., 1983; Dabbagh et al., 1984). The most recently-measured K-Ar ages were obtained from a basalt flow south of the town of Al Birk, $20 \mathrm{~km}$ south of Wadi Dabsa, placing it at $1.37 \pm 0.02$ and $1.25 \pm 00.02 \mathrm{Ma}$ (Bailey et al., 2007). Given the wide variation in surface erosion of the lava flows, the Harrat was likely formed through an extended period of punctuated volcanism, related to intra-plate volcanism similar to other Arabian harrat (Bosworth \& Stockli, 2016). The timing of this volcanism places it within the known timeframe of the earliest dated hominin dispersals out of Africa, 1.8 Ma (Ferring et al. 2011), meaning that it is possible that the landscape of the Harrat al Birk, and the resources it provided, underwent intermittent, significant transformation during 
the period in which hominin populations inhabited the region, changes which need to be understood before interpreting past hominin occupation of the region.

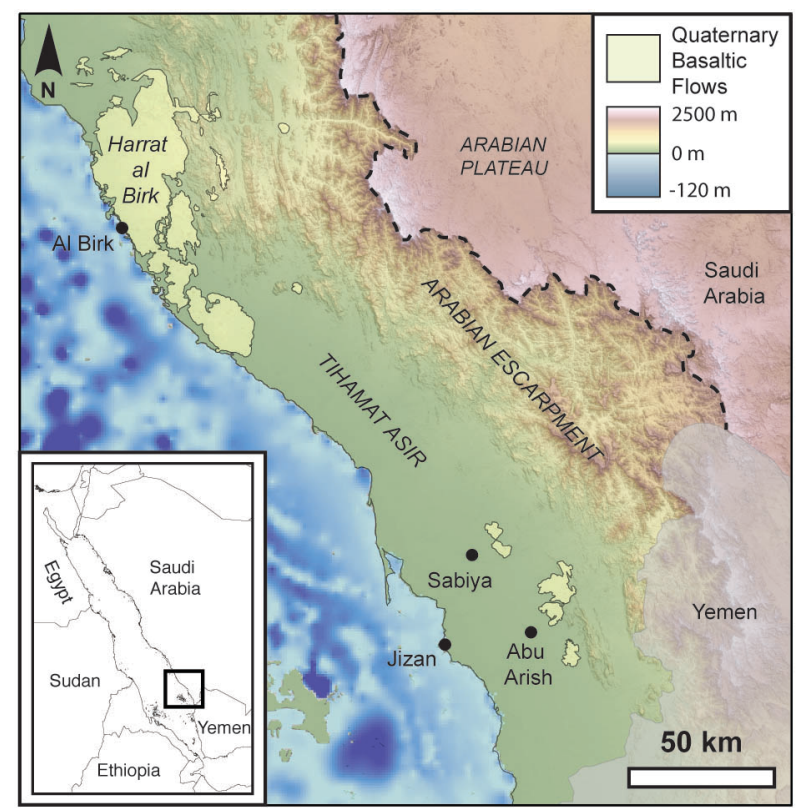

Figure 1: Study region location in southwestern Saudi Arabia. The Harrat al Birk is a major landscape feature interrupting the low-lying Tihamat Asir coastal plain that is bounded by the Arabian escarpment and the present-day coastline. Elevation data: ASTER GDEM 30m.

The Harrat is drained by deeply-incised wadis (up to 30-40m deep), with the incision in places exposing the underlying schistic bedrock. The wadis have occasionally been filled with later lava flows (e.g. Wadi Najla; Inglis et al., 2015). After rainfall (primarily during the winter months), water pools at points within the wadi channels. Tufa and other carbonate deposits precipitated by flowing and ponding of carbonate-rich water are common in the wadis, indicating past periods of increased water flow (Dabbagh et al., 1984). The steep topography of the wadis, and the roughness of the basaltic surface within the harrah, may have allowed the tracking and trapping of prey by hominin populations, as well as facilitating movement from the coastline into the interior (Kübler, King, Devès, Inglis, \& Bailey, In press).

A narrow (0.5-1 km wide) coastal plain consisting of sabkha and alluvial deposits abuts the western edge of the harrah. Marine deposits, in the form of beachrock and fossil coral, have been recorded at elevations of between 3 and $7.5 \mathrm{~m}$ asl in numerous locations along this coastline (Zarins et al., 1981; Dabbagh et al., 1984; Bailey et al., 2015). Whilst yet undated, it is likely that these past sea level indicators mark an MIS5e high sea stand (Inglis, Bosworth, Bailey, \& Rasul, In Press), indicating that during periods of high sea level, populations in the Harrat al Birk had access to marine resources. During periods of low sea level, however, including most of the last 70,000 years, the Red Sea coastline would have been further west, 
leaving the western edge of the Harrat al Birk up to $100 \mathrm{~km}$ from the sea during the Last Glacial Maximum (Lambeck et al., 2011; Bailey et al., 2015).

\section{Wadi Dabsa}

Wadi Dabsa drains the western side of the Harrat Al Birk, entering the Red Sea near Dabsa town. Two main tributaries begin in the basaltic flows to the east, joining just upstream of Dabsa, $4 \mathrm{~km}$ from the present-day coastline (Figure 2). The northern tributary runs NESW for approximately $12 \mathrm{~km}$, deeply incising basaltic flows before opening out to a wide channel where it joins the southern tributary. The southern tributary, the focus of investigations presented here, runs ENE-W for $\sim 7 \mathrm{~km}$ through the basaltic flows before a change in topography is marked by a widening of the channel prior just upstream of its junction with the northern tributary. Two kilometres upstream of the confluence, the southern tributary flows through a wide basin $800 \mathrm{~m} \times 1400 \mathrm{~m}$, the floor of which is almost completely covered by tufa carbonate deposits. The main channel, running along the contact between the tufa and adjacent basalt, incises the tufa to a depth of over $2 \mathrm{~m}$. A smaller but deeper ( $>4 \mathrm{~m}$ ) channel that incises both tufa and basalt flows from NE to SW across the centre of the tufa exposure, dividing it into what we have termed the western and eastern sub-basins. Tufa barrages are also present within the southern tributary wadi channel, as well as in the incised fan-shaped area where the wadi becomes unconstrained downstream of the western sub-basin (Figure 2). These tufa deposits have been incised to depths of over $6 \mathrm{~m}$ in places.

The Wadi Dabsa basin may have been particularly attractive to past populations given: (i) the presence of ponded and/or flowing water, recorded in the tufa deposits, including pool(paludal-) settings and fluvial barrages with morphologies indicative of both the presence of vegetation (reeds and mosses), and also inorganic surface drapes across the main basin, with the addition of a fluvial cascade to the west of the incised channel that emerges into the fan feature; (ii) extensive sources of raw material for artefact manufacture, in the form of the basalt flows; (iii) complex topography that allows the tracking and trapping of prey (King \& Bailey, 2006; Devès et al., 2014); and (iv) and the potentially favourable edaphic properties of soils developed on volcanic deposits (Kubler, Owenga, Reynolds, Rucina, \& King, 2015; Kübler et al., In Press). 


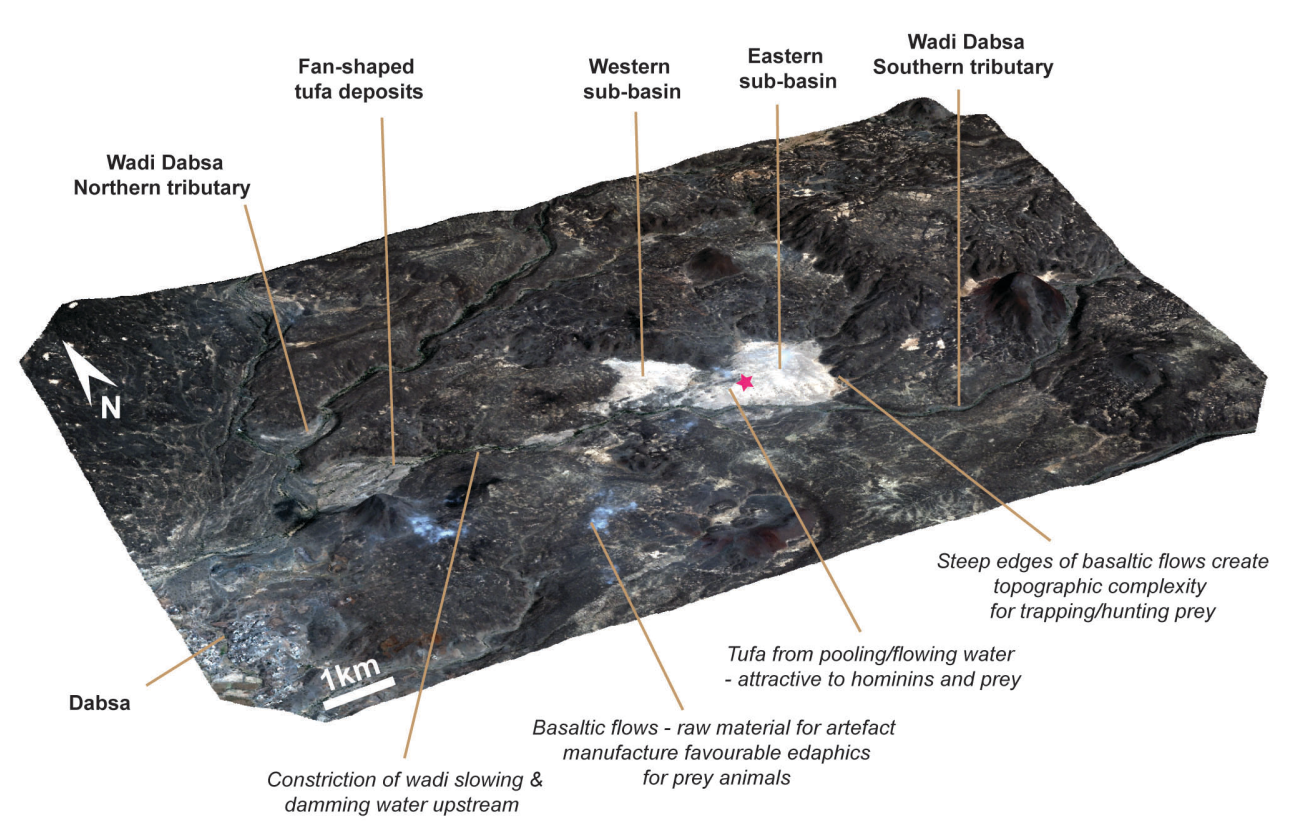

Figure 2: Overview of the Wadi Dabsa basin showing main topographical features (bold) and features potentially attractive to past hominin populations (italic). Elevation data: ASTER GDEM 30m (3x vertical exaggeration; Satellite image: Pléiades 1 Multispectral (30 m) true colour.

Initial survey of the basin in 2015 recorded numerous basalt artefacts lying on the surface of the tufa, at relatively high densities at one location in the centre of the basin (Inglis et al., 2015). Transects across the basin identified isolated basalt and quartz ESA, MSA and Later Stone Age (LSA) artefacts at other locations, including a large ESA handaxe on the basalt footslope at the north western edge of the basin (Foulds et al., 2017). Using a $50 \mathrm{x} 40 \mathrm{~m}$ grid (designated Locality 106, or L0106), 903 artefacts were collected from the surface of sediments overlying the tufa, yet the relationship of the artefacts to the underlying tufa remained unclear: some artefacts were observed underneath large loose tufa slabs suggesting that they may have weathered in situ from the tufa. Focussed investigation in 2017 sought to further record the extent, character and geomorphological setting of the L0106 artefacts in their wider landscape.

\section{METHODS}

Working from the kilometre- to metre-scale, an interdisciplinary approach to the Wadi Dabsa basin was employed to understand the basin's evolution, the stratigraphic relationship of the observed archaeology to this changing landscape, and the active and past geomorphological processes within the landscape that would have controlled the preservation, exposure and visibility of Palaeolithic artefacts. 


\subsection{Regional Landscape Mapping}

Landform units at the region scale were mapped using satellite imagery to develop a broad-scale understanding of the landscape and build a working landscape stratigraphy. Units were defined through the visual examination of Pléiades 1 satellite imagery which has 4 multispectral bands (dated 2/29/2016) with reference to the ASTER 30 m Global Digital Elevation Model (GDEM30m) as well as true colour satellite imagery accessed through Google Earth and mapped in QGIS 2.0. Units were defined by their geological and geomorphological origins and the processes that had most recently shaped them, e.g. basalt flows, basalt terraces, tufa. Observations were groundtruthed in 2017, and the data imported into ArcGIS 10.4.1 to allow visualisation. When dates become available, this working landscape stratigraphy will be timeconstrained using chronometric dating.

\subsection{Surface Classification Using Satellite Imagery}

The area of the basin underlain by tufa, defined in the regional mapping (Section 4.1), formed the main focus of investigation given the L0106 artefact accumulation was recorded on this unit. As observed on remote sensing imagery and in the field, the land surface on the tufa appeared to be quite variable, from bare tufa to fluvial and aeolian sediments, with very different implications for the preservation, exposure and visibility of artefacts. Understanding the variability of surface condition across the basin would therefore allow a first-level assessment of artefact visibility, and the specific geomorphological setting of the dense artefact accumulation.

Detailed remote mapping of surface condition was conducted using unsupervised, automatic classification of images from Google Earth (RGB) into 10 classes in ENVI 5.2 (output aggregated to 5 pixels and smoothed to 3 pixels). The resulting classes were assigned interpretations based on visual examination of the satellite imagery, and then groundtruthed through visits to eight locations within the basin.

\subsection{Investigations at the L0106 and L0130 Grids}

In 2015, a 40 x $50 \mathrm{~m}$ grid was established across the area of dense artefacts at L0106 and divided into $10 \times 10 \mathrm{~m}$ squares, with each square further subdivided into four $5 \times 5 \mathrm{~m}$ quadrants designated w, x, y, and z (Figure 3; Inglis et al., 2015). In 2017 this grid was extended NW by $20 \mathrm{~m}$, and a second $50 \times 60 \mathrm{~m}$ grid (L0130), offset from L0106 by $5 \mathrm{~m}$ to the northwest to avoid a road, was established and similarly divided into $10 \times 10 \mathrm{~m}$ squares and $5 \times 5 \mathrm{~m}$ quadrants. The position of additional artefacts, located within the basin but beyond the artefact 
collection girds, was recorded using either a Trimble Geo7X without an external antenna or a Garmin 62s handheld GPS, with each piece assigned a unique waypoint number.
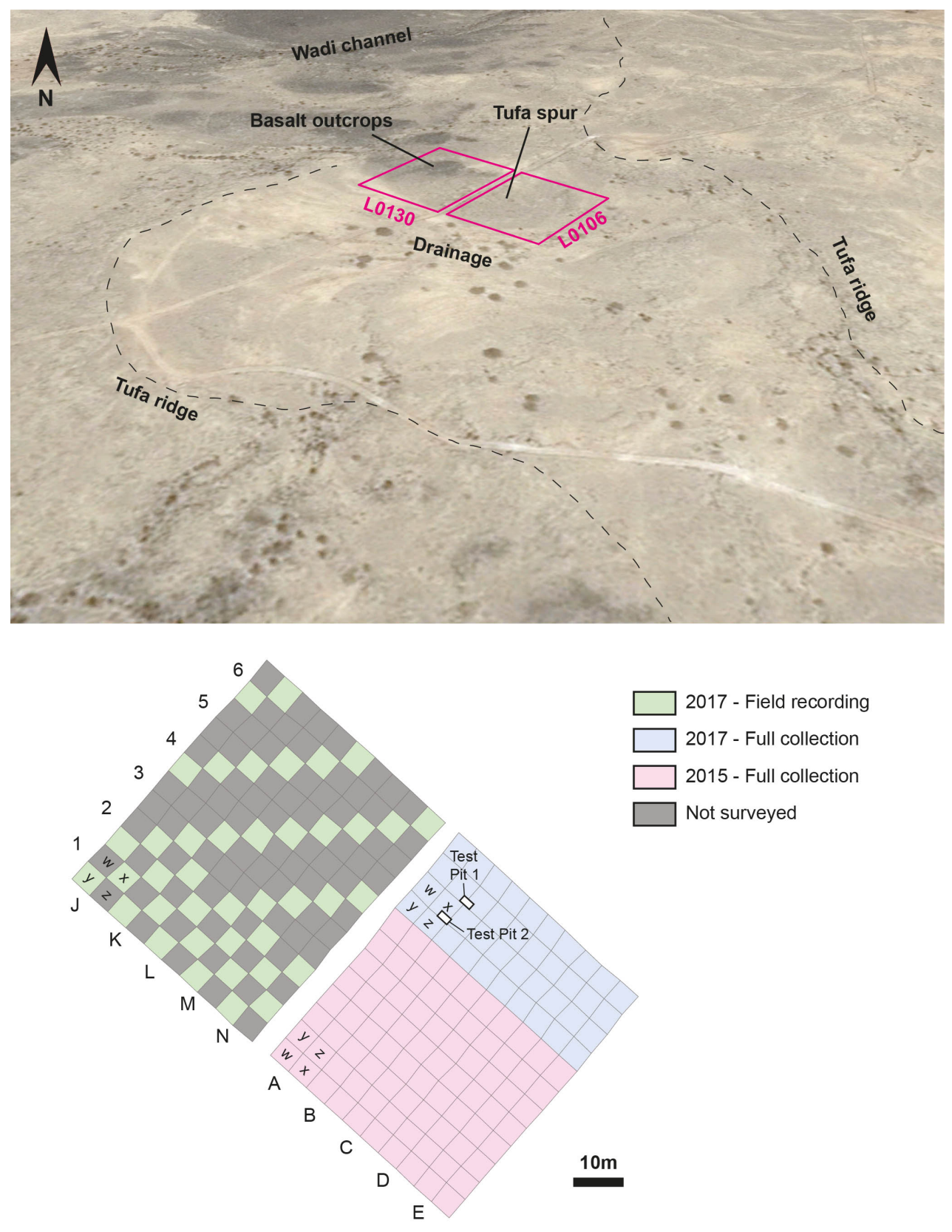

Figure 3: a) Artefact recording grids L0106 and L0130 in their landscape setting, on a tufa spur between two tufa terraces. Drainage is broadly $E / W$ in this part of the basin. b) Artefact recording methodologies and quadrant naming methods employed across the grids and season of survey, and location of test pits. Imagery: (C) CNES/Airbus accessed through Google Earth, imagery date 15/11/2016. 
Topographical survey. Obtaining a robust model of the topography of the grid was key to understanding the impact of local geomorphological processes, as was locating the grids accurately within the wider landform and surface mapping. The corners of each quadrant in both grids were surveyed using a Trimble Geo7X and Zephyr Model 2 external antenna running ArcPad 10, and their relative heights measured using a dumpy level and staff for increased vertical precision in this relatively low relief terrain. This data was used to create a Triangulated Irregular Network (TIN), and a Digital Terrain Model (DTM) in ArcMap.

Landform mapping. The grids covered a variety of landform units at the small scale, each with different implications for the preservation, exposure and visibility of artefacts. Landform units, defined as areas of relatively uniform surface morphology, were mapped across the two grids by recording their boundaries as polylines in ArcPad10 using the Trimble and external antennae. The polylines were later used to generate polygons of each landform unit in ArcMap.

Surface condition within each of the defined landform units is variable and affects the visibility of artefacts. The main surface condition types were described within each quadrant across the grid where artefacts were collected or recorded, as well as the percentage of the quadrant that comprised bare tufa surface.

Artefact collection and recording: The artefacts within the grids were sampled using two complementary strategies. All surface artefacts visible within grid L0106 were collected and bagged by quadrant for post-excavation analysis. Rows 1-4 were collected in 2015, and Rows 5-6 in 2017, providing a 100\% sample of the surface artefacts in L0106 $\left(3,000 \mathrm{~m}^{2}\right)$. In L0130 a restricted sampling and recording-only strategy was employed to: a) determine the extent of the artefacts across the tufa surface; and b) document their typologies for comparison to those observed in L0106; whilst c) leaving a significant sample of the artefacts in their geomorphological context for future potential study. Quadrants y and $\mathrm{x}$ of alternate squares in Rows 3-6, and all squares in Rows 1-2 were surveyed (total sample: $33 \%, 1,000 \mathrm{~m}^{2}$ ) and the artefacts photographed and basic attributes recorded before being left in the field. Artefacts collected from the locality prior to the establishment of the grid, or lying outside the grid were collected for analysis after recording of their locations using a handheld Garmin 62s GPS.

Test pits: To investigate the depth and nature of the sediments overlying the tufa, two small test pits were dug in Quadrants 6Az/By (Test Pit 1) and 5Ax (Test Pit 2) of L0106, in the 'Crest' landform unit (Section 4.3.1) where artefacts were most abundant (Figure 3). Each pit 
was begun as a $0.5 \times 0.5 \mathrm{~m}$ square, before extension to $0.5 \times 1 \mathrm{~m}$. After the first $0.5 \times 0.5 \mathrm{~m}$ sondage, during which all lithics were bagged together, the extensions were excavated stratigraphically, with contexts defined based on lithological changes and lithics bagged according to context.

Bulk sedimentology: Basic sedimentological analyses of the $<2 \mathrm{~mm}$ fraction were undertaken to characterise the sediments exposed within the test pits and aid their interpretation. Percent organics (\%LOI organics) and percent carbonate (\%LOI carbonates) for the test pit samples were determined by loss on ignition, heating the dry samples sequentially to $550^{\circ} \mathrm{C}$ and $950^{\circ} \mathrm{C}$ respectively and noting the mass loss. Measurement of the low ( $\left.\chi \mathrm{lf}\right)$ and high $(\chi \mathrm{hf})$, frequency mass magnetic susceptibility of the test pit sediments was carried out using a Bartington Instruments MS2, 294 consisting of a Magnetic Susceptibility Meter MS2 and MS2B 295 Dual Frequency Sensor. Percent frequency dependent susceptibility ( $\chi \mathrm{fd})$ was calculated for each of the samples.

Particle size analysis was undertaken using a Malvern Mastersizer 2000 following dispersal of the sediment in water, with subsamples measured both with and without dissolution of carbonates using $37 \% \mathrm{HCl}$. The latter set allowed comparison of the non-carbonate material in the sediment with the residue derived from a loose block of tufa collected from the grid surface after dissolution with $37 \% \mathrm{HCl}$ to further understand the origin of the sediment unit overlying the tufa (see below).

Data storage and display: All data from the artefact collection grids was collated in shapefiles in ArcGIS, to allow the visualisation of the data across the grids in both two and three dimensions. The data will be deposited with the Archaeology Data Service, for open access in perpetuity.

Chronometric sampling: Samples for chronometric analysis were collected from tufa deposits (U-Series dating, ${ }^{234} \mathrm{U}^{2}{ }^{230} \mathrm{Th}$ ) and basalt flows (Argon-Argon dating, ${ }^{40} \mathrm{Ar} /{ }^{39} \mathrm{Ar}$ ) representative locations across the basin (locations reported in Inglis et al., 2017). The samples are currently undergoing analysis at the British Geological Survey, Keyworth, and the Scottish Universities Environmental Research Centre, East Kilbride respectively. 


\section{RESULTS}

\subsection{Regional Landform Mapping and Landscape Stratigraphy}

Visual mapping of landform units from the satellite imagery was aided by the general lack of vegetation in the region. The regional landscape is dominated by basaltic lava flows, some of which can be associated with specific cinder cones (e.g., flow F1 appears to have originated from cinder cone $\mathrm{C} 1$ as shown in Figure 4), and their stratigraphic relationships to earlier and later flows are easily defined. Other flows have less obvious origins, or less clear boundaries. The tufa deposits (covering around $1 \mathrm{~km}^{2}$ ) are constrained to topographic lows, primarily in the main basin and incised wadi channels.

A working landscape stratigraphy, with identified relationships marked by arrows, is presented in Figure 4. A sequence of flow emplacement, from older to younger flows, is proposed, extending from the southwest, where the weathered condition indicates an older age of the volcanic deposits, towards the northeast, where well-defined flows, likely from more recent eruptions, emanate from the $\mathrm{C} 1, \mathrm{C} 2$ and $\mathrm{C} 3$ cones.

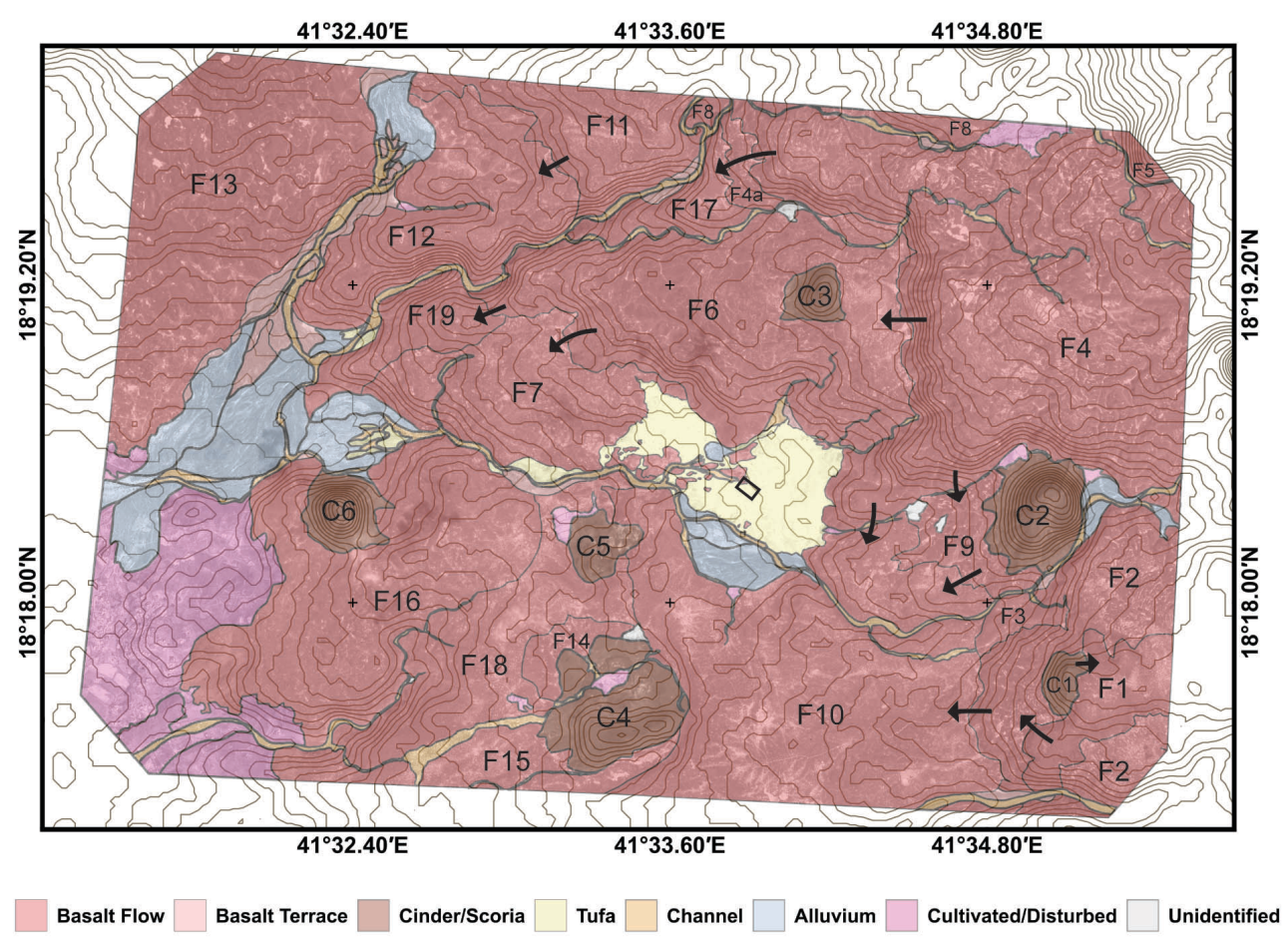

Figure 4: Map of the Wadi Dabsa basin study area, showing landform units classified from remote sensing data, and relationships between basalt flows as interpreted from remote observations, indicated by arrows. In each instance, arrows originate in the younger flow. Contour interval $5 \mathrm{~m}$. Elevation data: ASTER GDEM 30m. Satellite image: Pléiades 1 Multispectral $(30 \mathrm{~m})$ true colour. 
Tufa comprises the major sedimentary unit within the basin, and within the fan-shaped deposit downstream (to the west), with smaller patches of tufa in the wadi channels that link these areas (Figure 4). A $220 \mathrm{~m}$-long incised section of the wadi marks the southwestern boundary of the two main sub-basins, which to the east separates tufa and alluvium surface cover, and further east marks the contact with the adjacent basalt. The surface of tufa in the eastern sub-basin slopes ENE-WSW, from $\sim 124$ to $\sim 89 \mathrm{~m}$ asl (ASTER GDEM 30m), and the main drainage is consequently $\mathrm{E}-\mathrm{W}$; $\mathrm{N}-\mathrm{S}$ orientated, low, eroded barrages to the west of the L0106/L0130 artefact grids in the eastern sub-basin also suggest that, in this area in the past, water predominantly flowed $\mathrm{E}-\mathrm{W}$, emanating from the direction of basalt flows $\mathrm{F} 4$ and F9 (Figure 4).

The Wadi Dabsa tufa includes pool- (or paludal-) type, and fluvial barrage and fluvial cascade features, as well as surface drapes ('flowstone-type', akin to flowstone in caves) (Figure 5). In the incised channel at the southwest of the eastern sub-basin, the thickness of exposed tufa unit suggests it may be of the fluvial cascade type (a greater size than a fluvial barrage), although it is possible these thick units have greater lateral extent under the main basin. There may have been a role for spring-flow into the basin, although there are no obvious spring-mound, or pinnacle, features preserved. To the west of the main basin(s), where a fanshaped feature emerges there is a large fluvial cascade feature, which is relatively flat-topped and around $8 \mathrm{~m}$ thick, with some post-depositional incision and erosion. In terms of field (or macro-) morphology, within the basin(s) there are: massive tufa sheets, up to $\sim 1 \mathrm{~m}$ thick, sometimes intact (Figure 5a) and sometimes highly broken up (Figure 5b), which are relatively dense, some with obvious phytoherm framework (Figure 5c) and others with little evidence of former plantlife; phytoherm framework tufa deposits, both in clumps in flat topography (Figure 5c) and within the fluvial barrages (Figure 5d) and cascades (Figure 5f); tufa-cemented clastrich units, particularly observed within incised channels (Figure 5g) and eroded cascades (Figure 5f) and inorganic thin drapes (the flowstone-type; Figure 5f). Together, these deposits clearly indicate phases of greater moisture availability in the landscape in the past, involving standing and running water. The overall distribution, range of settings and stratigraphy (where observable) suggests that these deposits may result from repeated periods of wetter conditions in the basin. Within the incised channel at the southwest of the eastern sub-basin there is an exposed $>2 \mathrm{~m}$ section of tufa material, composed of various macromorphological types massive tufa sheets (Figure 5a,b), phytoherm (Figure 5c-g), tufa-cemented clasts from boulder to gravel size (Figure $5 \mathrm{f}, \mathrm{g}$ ). As noted above, it is not yet clear whether this depth of tufa is 
localised to this southern edge of basin, where water was flowing (as a cascade feature), or whether it is representative of the depth of deposits across the basin (vertical profiles into the basin would have to be drilled to investigate this further).
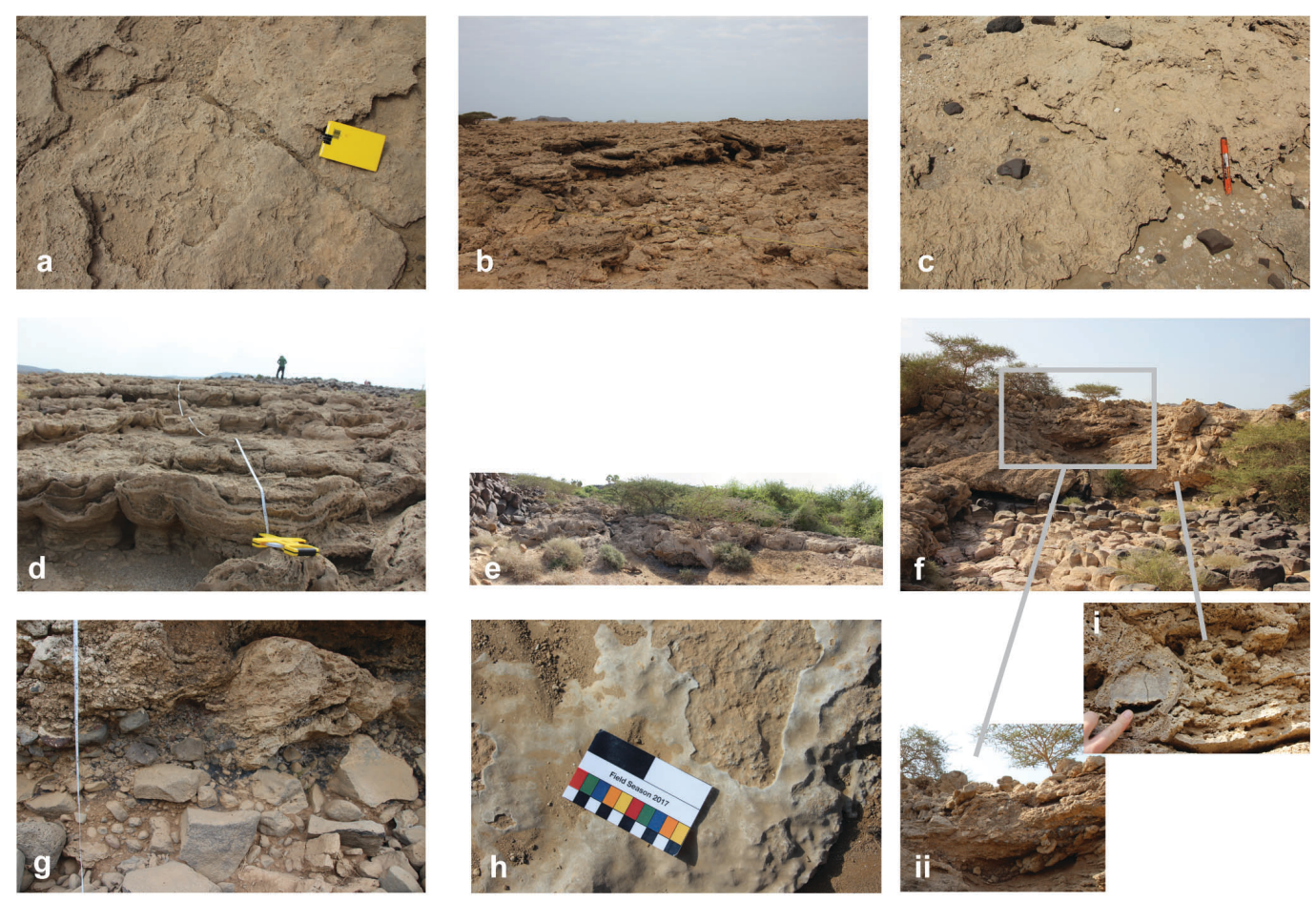

Figure 5: Examples of tufa depositional settings and macro-morphological groups in the Wadi Dabsa Basin: (a) pool-type setting, massive tufa sheets; (b) pool-type setting, broken-up massive sheets; (c) pool-type setting, phytoherm macromorphology; (d) fluvial barrage setting, phytoherm macromorphology, with distinct overhanging barrage bulge; (e) fluvial barrage setting, made up of phytoherm macromorphology across the channel width, and lacking the distinct overhanging bulge shapes; (f) fluvial cascade setting, found downstream of main Wadi Basins at the fan site, containing both phytoherm macromorphology (inset (i)) and tufacemented clast-rich units (inset (ii)); (g) small cascade or large fluvial-based deposit (within incised channel to south of main basins), detailing tufa-cemented clasts and phytoherm macromorphology; (h) surface-drape setting, made of organic-poor crust. Photos: A. Stone.

Whilst it appeared from the satellite imagery that nearly all the basalt flows underlie, and were therefore emplaced before, the tufa, the lobate form of the southwestern arm of F4 suggests that it may have been emplaced after tufa deposition. The stratigraphically youngest flow in contact with the tufa, F4, appears to have followed the course of an existing drainage channel that emptied into the basin (Figure 4). Given the impact the emplacement of F4 would have had on the basin's hydrology, potentially blocking a source of water flow into the basin, understanding the relationship between the tufa and this basalt flow was of high priority for understanding the attractiveness of the area to hominins. At all locations in the field where the contact between tufa and basalt could be observed (difficult in areas where unconsolidated 
aeolian and alluvial sand had collected), the tufa overlay and thus post-dated the basalt. At the southwestern lobe of F4, a small patch of tufa overlay the base of the flow, indicating that here too, a period of tufa deposition had post-dated emplacement of F4. It therefore appears from the observations to date that tufa deposition occurred within a basin whose morphology was defined and occasionally modified by the morphology of the basalt flows. Given the complexity of the tufa formation across the basin, however, the potential for interleaved or coeval deposition of lava flows and tufa cannot be dismissed.

\subsection{Surface classification and groundtruthing}

Unsupervised landscape classification, using Google Earth imagery (RGB), of the Wadi Dabsa basin and its immediate surroundings into ten land surface classes included three classes related to the main areas of sedimentation conditions on the surface of the tufa (Classes Eight to Ten), and seven classes corresponding to differences in the surfaces of the surrounding basalt flows, as well as areas where basalt is exposed in wadis crossing the basin (Classes One to Seven, Figure 6). From satellite observations, these three main tufa surface classifications were interpreted as corresponding to: bare surfaces composed of tufa (Class Nine, Dark Red in Figure 6); bare tufa surfaces, potentially weathered and 'polished' (Class Eight, Blue-green); and unconsolidated sediments (Class Ten, Bright Green).

Classifications and their interpretations were groundtruthed with visits to eight locations across the surface of the tufa where different classes were identified (Figure 6a, Table 1). Broadly, the classes correspond to: tufa surfaces with very little or no sediment cover (Class Nine, Dark Red; Figure 6b); areas of tufa or sediment with a significant amount of basalt clasts, from gravel to boulders, scattered across the surface (Class Eight, Blue-Green; Figure 6c); and unconsolidated sediment (Class Ten, Bright Green). This latter class encompasses fine-grained aeolian deposits; sandy to gravelly lag/pavement deposits overlying tufa (Figure 6d, e); outcrops of grey silty material that has a buff-coloured wind-blown dust veneer (Figure 6f); and sediment in shallow drainage channels and depressions (Figure 6g). 


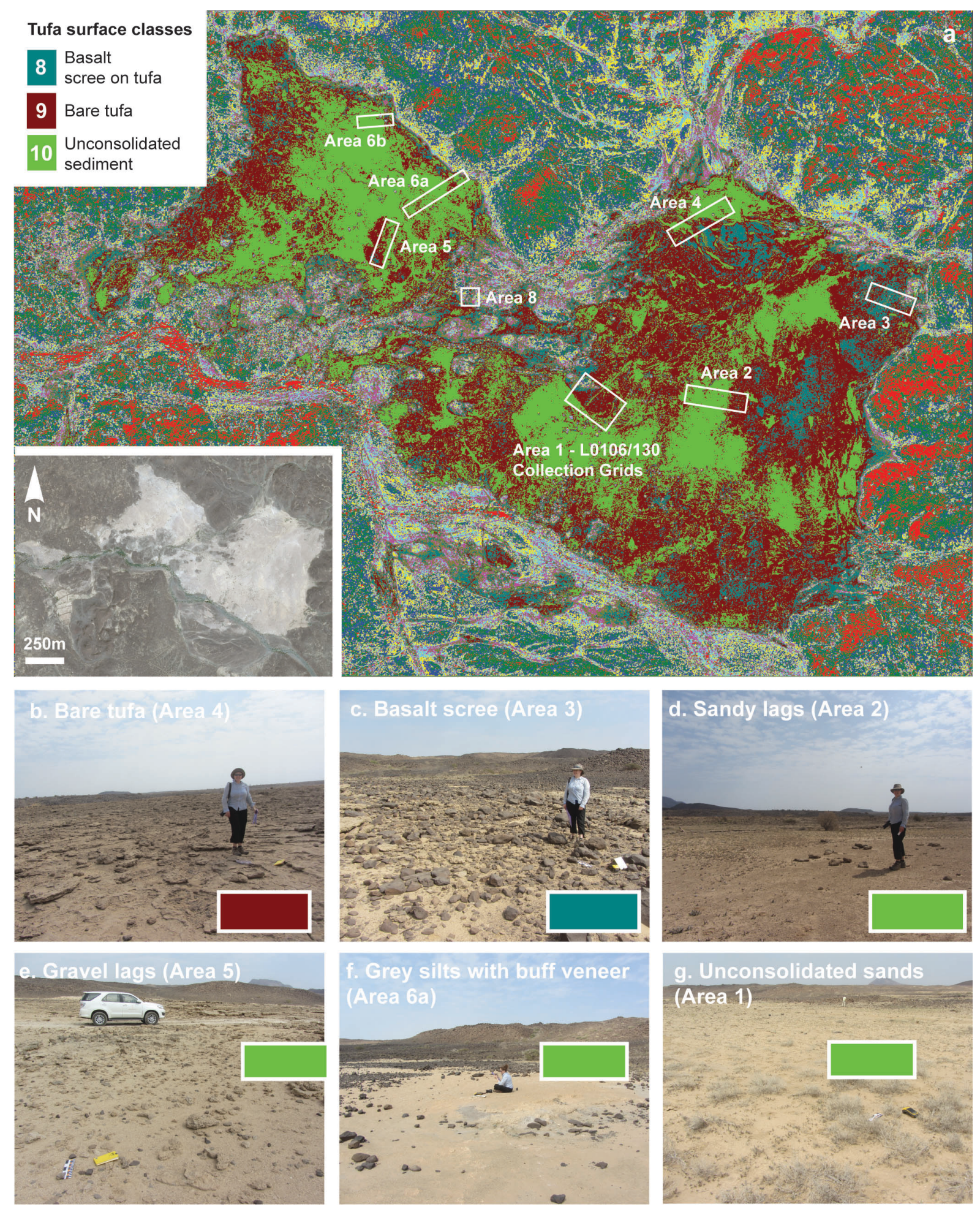

Figure 6: a) Unsupervised surface sediment classification of Google Earth Imagery in the Wadi Dabsa basin, with groundtruthing locations (Table 1) marked; b-g) photos of example surface conditions in the field in each unsupervised mapping class. Satellite imagery (C) CNES/Airbus, Imagery date 19/01/2014, accessed through Google Earth. Photos: R. Inglis. 
Table 1: Unsupervised surface classification class and condition at each of the locations shown in Figure 6.

\begin{tabular}{|c|c|c|c|}
\hline Location & $\begin{array}{l}\text { Bright Green } \\
\text { (Class Eight) }\end{array}$ & $\begin{array}{c}\text { Dark Red } \\
\text { (Class Nine) }\end{array}$ & $\begin{array}{l}\text { Blue-Green } \\
\text { (Class Ten) }\end{array}$ \\
\hline 1 & $\begin{array}{l}\text { Unconsolidated silty sand in } \\
\text { drainage area. }\end{array}$ & $\begin{array}{l}\text { Tufa terraces with } \\
\text { pockets of silty sand } \\
\text { sediment. }\end{array}$ & - \\
\hline 2 & $\begin{array}{c}\text { Silty sand with tufa gravel lag } \\
\text { deposit on surface. }\end{array}$ & Bare tufa surface & - \\
\hline 3 & - & Bare tufa surface & Basalt gravel and boulders. \\
\hline 4 & $\begin{array}{l}\text { Unconsolidated silty sand, } \\
\text { sometimes with mollusc shells }\end{array}$ & Bare tufa surface & $\begin{array}{c}\text { Basalt coarse sand and } \\
\text { gravel overlying } \\
\text { unconsolidated silty sand. }\end{array}$ \\
\hline 5 & $\begin{array}{l}\text { Platy tufa gravel lag/pavement } \\
\text { overlying sandy silt. }\end{array}$ & - & - \\
\hline $\mathbf{6 a}$ & $\begin{array}{c}\text { Weathered tufa; tufa gravel } \\
\text { lag on silty sand sediment. } \\
\text { Tufa gravel lag on substrate } \\
\text { outcrop. }\end{array}$ & Bare tufa surface & $\begin{array}{l}\text { Basalt gravel and cobbles } \\
\text { over silty sand. }\end{array}$ \\
\hline 6b & $\begin{array}{l}\text { Buff-coloured surface of grey } \\
\text { substrate; bare tufa ridges } \\
<50 \mathrm{~cm} \text { wide }\end{array}$ & & Basalt scree \\
\hline 8 & \multicolumn{3}{|c|}{ Mixture of tufa and basalt cobbles, patches of sandy sediment, and vegetation. } \\
\hline
\end{tabular}


Groundtruthing clearly identified broad variations in surface cover, as well as clarifying the nature of Class Eight as the result of significant amounts of basalt scree. Yet the variability in surface conditions within Class Ten (e.g., 'pavement' lag deposits vs mobile, unconsolidated sediment) contained settings which have very different impacts on artefact visibility - the observation of a basalt core on a lag/pavement surface in Area Five demonstrates good visibility of material on this 'pavement' surface, compared with low to no visibility on unconsolidated sediments along drainage lines (e.g. Area One, L0106/0130 survey grids).

\subsection{The L0106/0130 Survey Grids}

Artefact survey grids L0106 and L0130 are situated on the top and S/SW facing slope of a linear ridge of preserved tufa that extends SE from a basalt outcrop (Figure 3). To the north of the grids, after a small plateau ( $\sim 20 \mathrm{~m}$ wide), the surface of the tufa again rises, whilst to the SE and SW of the grid a broad drainage depression drains water broadly E-W across the surface of the tufa, dropping SW 150m west of the site. The grids themselves slope gently NESW along the SW side of the tufa ridge, with an overall change in elevation of $2 \mathrm{~m}$. A bulldozed road runs SW-NE through the centre of the artefact concentration, and an Islamic burial cairn built of tufa slabs and basalt blocks takes up most of Square 5D.

\subsubsection{Landform Mapping}

The automatic classification of the tufa surface (described in Section 4.2) identified two main surface classes in the area covered by the grids, namely bare tufa and unconsolidated sediment (Area One; Figure 6). To refine the classification of the landforms at the scale of the L0106/L0130 grid, six landform units were defined within the grids in the field, the shape of which broadly follow the boundaries of the unsupervised classification (Figure 7):

Ridge: Forming the highest part of the survey area in the northwestern section of L0130, this unit is characterised by a basalt outcrop consisting of rounded to sub-angular basalt boulders, cobbles and gravel. It also occurs as minor basalt outcrops at the southeastern end of the rise in L0106 within the 'Crest' unit. In L0106, the surface between the basalt rocks is covered with fine to coarse, angular to sub-rounded, basalt gravel mixed with what looks like fine-grained, potentially pedogenic, carbonate nodules. In L0130, the surface between the rocks varies from this carbonate gravel to silty sand. 

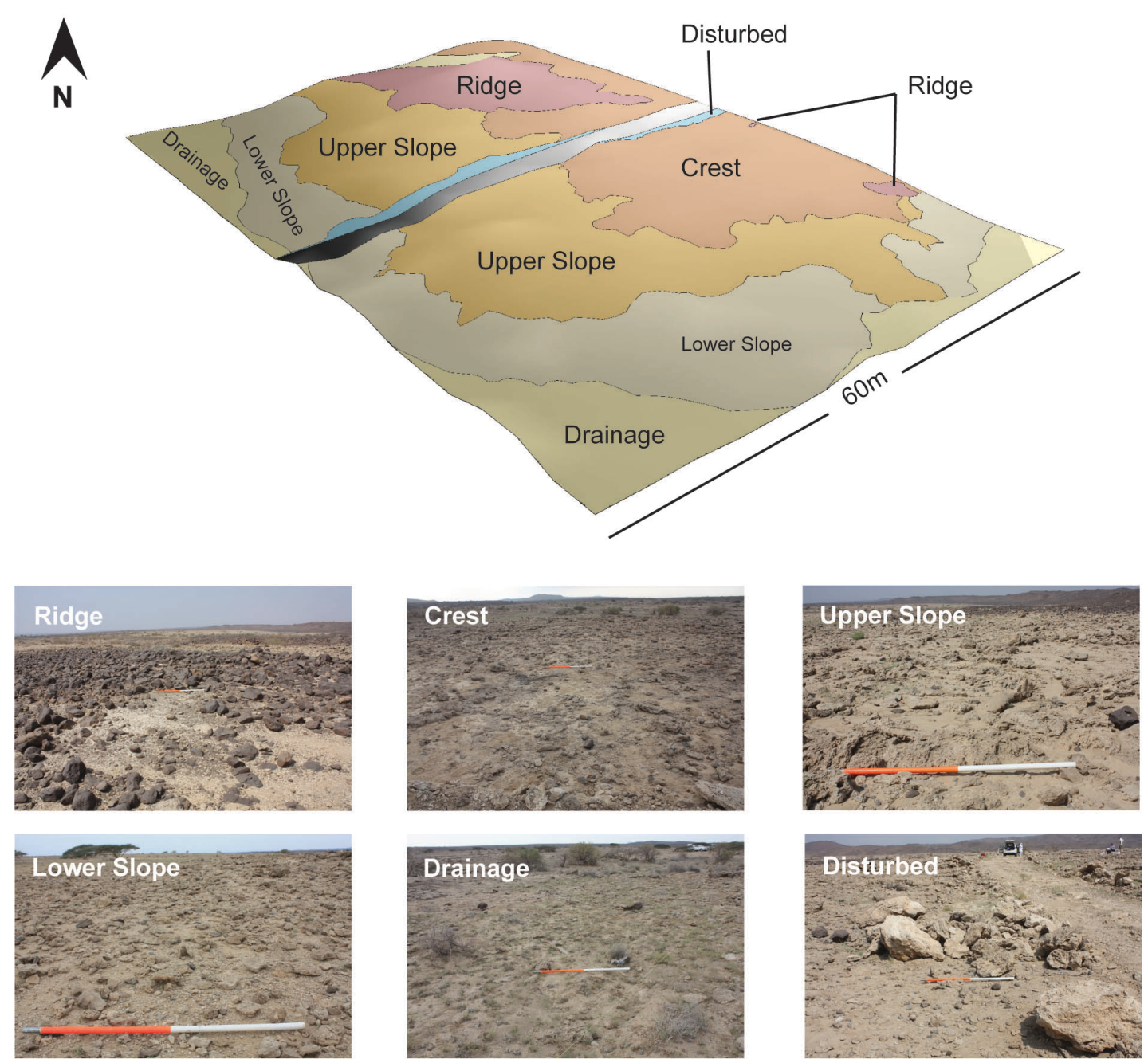

Figure 7: Topographic map of landform units defined across Grids L0106/0130, and photos of surface condition within each landform. Photos: P. Fanning

Crest: This unit comprises the broad, flat surface of the northwest to southeast trending ridge. The surface is predominantly in situ tufa in L0106 and basalt in L0130, with patches of buff-coloured silty sand becoming more extensive to the northeast.

Upper Slope: A stepped surface of tufa on the southwest-facing slope of the grids. The surface is mostly bare in situ tufa in L0106, with tufa and basalt cobbles in L0130, with patches of sandy to gravelly sediment on the flat treads of the terraces.

Lower Slope: A low-angled footslope towards base of the southwest-facing slope of the survey grids. The surface consists of rare exposures of in situ tufa, with tufa and basalt gravel and cobbles lying on sandy to gravelly sediment. Basalt gravel and cobbles are more abundant 
towards the northwestern boundary of L0130. Plant growth was present at the time of survey but was very sparse.

Drainage: This unit is characterised by a relatively low-angled drainage depression bordering the grids to the east, south and southwest. In the northeastern section of L0130, it takes the form of an eroding drainage line leading downslope northwest from the Crest unit. In the eastern corner of L0106, this unit consists of numerous shallow rills through sandy, gravelly sediment. Plant growth is more abundant in this unit than any of the others, indicating occasional water flow or accessible water at shallow depth. At the south/southwest boundary of the grids, this landform unit has flatter topography and marks the distal margin of the drainage depression at the base of the southwest-facing slope. The surface here is covered with sediment, mostly buff-coloured silty fine sand. There are rare gravels and cobbles on the surface, and sparse plant growth. Shallow distributary rill channels indicate that water periodically flows across this surface.

Disturbed: This unit comprises narrow strips of land on either side of the bulldozed road that separates L0106 from L0130, where construction has disturbed the original surface, and inverted and redeposited large boulders of tufa.

In addition to the broad landform units, the percentage of the surface of each quadrant covered by bare, in situ tufa was recorded.

\subsubsection{Test Pit Excavations}

\section{Stratigraphy and Sediments}

The two test pits excavated within the Crest landform unit (Quadrants 6Az/6By and $5 \mathrm{Ax}$ ) both contain the same stratigraphy: a buff-coloured silty fine sand layer of variable thickness $(\sim 5-10 \mathrm{~cm})$ overlies, with a clear boundary, grey, silty fine sand $(\sim 20-25 \mathrm{~cm}$ thick), which has an abrupt but irregular lower boundary with the underlying tufa unit (Figure 8). Both units contain occasional, irregularly shaped subangular weathered tufa material, poorly sorted and ranging in size from gravel to boulders, as well as rare basalt boulders, and basalt artefacts. 

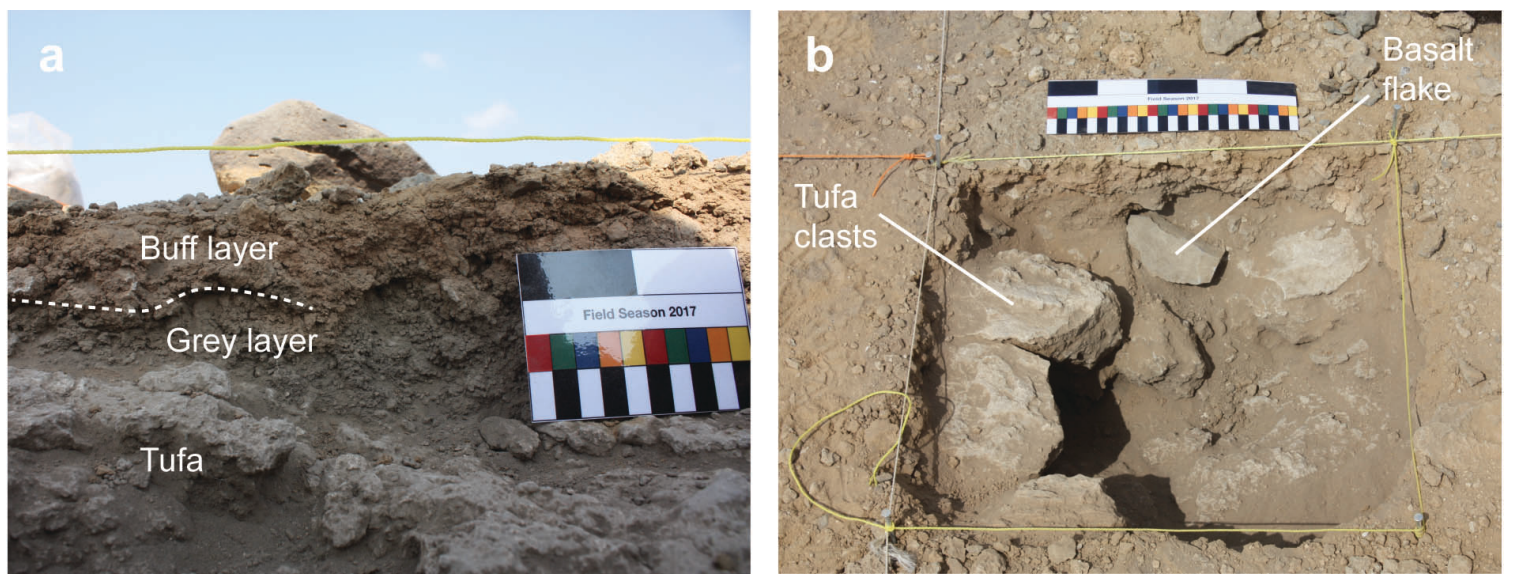

Figure 8: Images of Test Pit 1 prior to extension showing a) the section (scale is $10 \mathrm{~cm}$ ), and b) plan views (scale is $25 \mathrm{~cm}$ ). The former shows the buff-coloured sediment overlying the grey, while in the latter, an artefact amongst tufa clasts within the grey unit is indicated. Photos: H. Robson.

Laser particle size analysis of the $<2 \mathrm{~mm}$ sediment fraction of the test pit sediments (Figure 9) indicates a broad similarity in the particle size distributions of the layers exposed in the test pit stratigraphy, with moderately to poorly-sorted particles between $250-0.89 \mu \mathrm{m}$ in size. Removal of carbonates has a negligible effect on the PSD of the grey layer, although in the case of the buff layer, it appears to remove the small sand peak and increasing the percentage volume of material in the size range 100-1 $\mu \mathrm{m}$. The PSD of the tufa residue after carbonate dissolution comprises sediments within the same range as that of the sediment layers, but with two differences: it contains a better sorted coarse silt/fine sand peak centred around $30-50 \mu \mathrm{m}$, as well as a small, non-carbonate coarse sand.

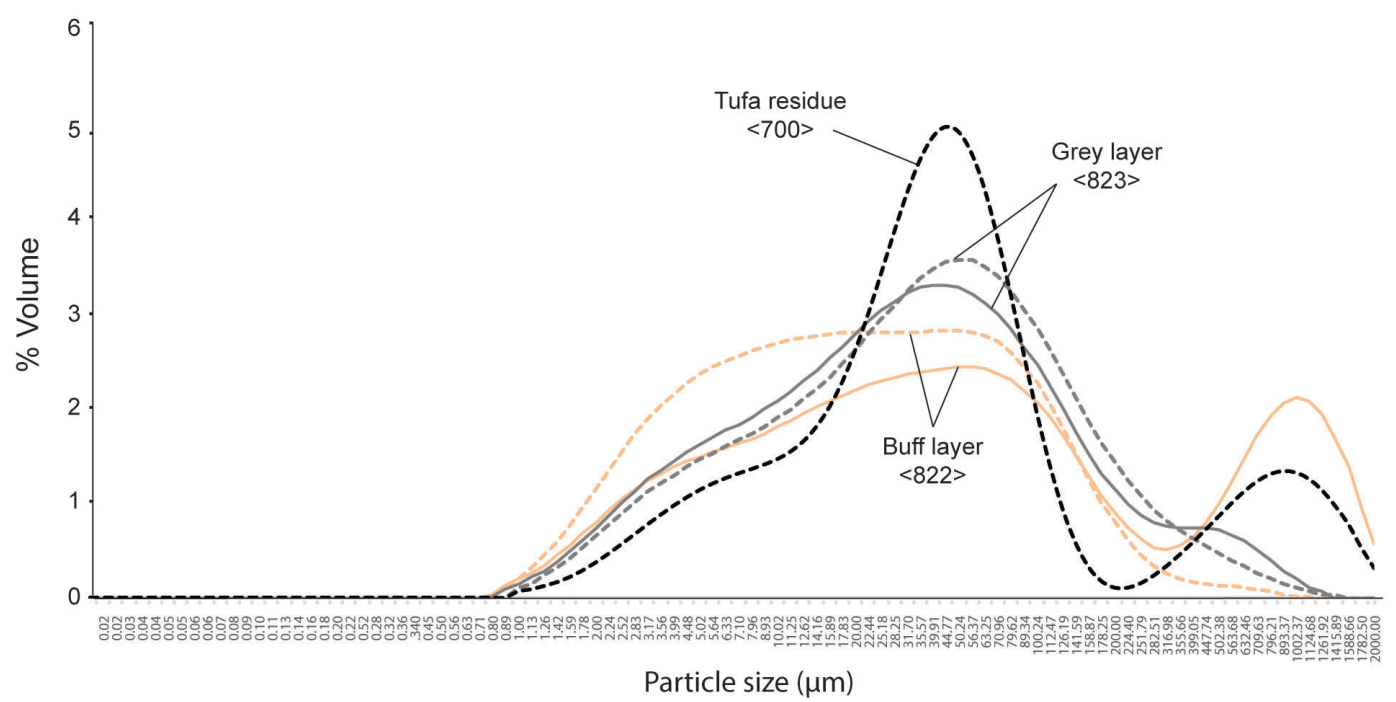

Figure 9: $<2 \mathrm{~mm}$ particle size distributions for layers exposed in test. Solid lines indicate sample without pre-treatment; dashed lines indicate samples with $\mathrm{HCl}$ pre-treatment and removal of carbonates. 
Table 2: Bulk sedimentological properties for samples from Test Pit 1.

\begin{tabular}{|c|c|c|c|c|c|}
\hline \multirow{2}{*}{ Sample } & \multirow{2}{*}{$\begin{array}{l}\% \text { LOI } \\
\text { organics }\end{array}$} & \multirow{2}{*}{$\begin{array}{l}\text { \%LOI } \\
\text { carbonates }\end{array}$} & \multicolumn{3}{|c|}{$\begin{array}{l}\text { Mass specific magnetic susceptibility } \\
\qquad\left(10^{-6} \mathrm{~m}^{3} \mathrm{~kg}^{-1}\right)\end{array}$} \\
\hline & & & $\begin{array}{c}\text { Low Frequency } \\
(\chi \mathrm{lf})\end{array}$ & $\begin{array}{c}\text { High Frequency } \\
(\chi \mathbf{h f})\end{array}$ & $\begin{array}{c}\% \text { Frequency } \\
\text { Dependent }(\chi \mathrm{fd} \%)\end{array}$ \\
\hline$<822>$ Buff & 2.97 & 8.21 & 261.1 & 259.9 & 0.5 \\
\hline$<823>$ Grey & 6.34 & 7.28 & 87.8 & 86.7 & 1.3 \\
\hline
\end{tabular}

The buff layer has a higher $\chi$ lf than the grey layer (Table 2), indicating a higher content of ferromagnetic minerals in the former. Given the low $\chi \mathrm{fd} \%$, it appears that there are very little, if any, superparamagnetic minerals within the two sediments (Dearing et al., 1996). The low $\chi$ lf of the grey layer indicates a general lack of ferromagnetic minerals; the value of the texturally similar buff layer, by contrast, is higher. The grey layer is higher in organic content than the buff $(2.97 \%$ and $6.34 \%$ respectively), although the carbonate content of the two samples are broadly similar $-8.21 \%$ in the buff layer, and $7.28 \%$ in the grey layer.

The bulk sedimentological observations support an interpretation of the buff layer as an active weathering layer of the grey sediment: the PSDs are largely similar between the two layers, save for the small coarse peak in the buff silt (which is not present in the non-carbonate PSD, indicating that it may consist of fine carbonate sand), that either was never present, or has been removed from, the underlying grey layer. The difference in $\chi$ lf between the layers may be the result of wetting and drying of the sediment, oxidising iron present in the surface sediment and thereby increasing the proportion of ferromagnetic minerals in the buff layer, also contributing to its redder colour relative to the grey sediment beneath. This grey-to-red colour change was also observed in Sample $<823>$ when the sample was burnt at high temperature during the LOI analyses.

The mechanisms controlling the organic content are less clear but may reflect the limited amount of organic material preserved in the grey layer breaking down through oxidation and surface weathering in the buff layer. Given the small number of samples, it is unclear how far a difference of a single percentage point in \%LOI carbonates indicates a meaningful difference in composition between the samples yet may reflect the variation in small amounts of carbonate sand identified through the PSDs.

These data offer some insights into the relationship between the tufa and the overlying sediment. The abrupt tufa/sediment boundary suggests deposition of transported sediment over a tufa surface, rather than the sediment being a product of the weathering of the tufa. Fragments of tufa observed within the grey and buff sediments may have weathered sub-aerially, rather than being remnants of a partially weathered tufa unit. The PSDs of the grey and buff sediments 
show that they are both composed of poorly sorted clayey silts, perhaps indicating deposition through shallow overland flow; the greater degree of sorting in similarly-sized material in the tufa residue may be the result of faster flowing water during tufa formation.

\section{Excavated Artefacts}

A total of 61 lithic artefacts were recovered from the test pit excavations, 13 from the buff layer (2 MSA, 11 non-diagnostic) and 27 from the grey (4 MSA, 1 LSA and 22 nondiagnostic). The initial sondage of each pit did not distinguish sediment layers, therefore the 21 artefacts excavated in this sondage (1 ESA; 2 MSA; 18 non-diagnostic) cannot be assigned to either layer. When separated by layer, the artefacts exhibit distinct differences in surface characteristics: those from the grey layer all possess a greyish patina and sharp edges, while those from the buff layer exhibit a range of weathering states from sharp/patinated to dark brown polished surfaces with subangular to subrounded edges similar to the outcropping basalt (Figure 11).

These observations suggest that at least some of the artefacts recovered from the buff layer originated in a similar sedimentary context to the grey layer. The presence of partially polished artefacts in the buff layer support the hypothesis that this layer is an actively deflating and weathering zone of the grey sediments, as their grey patina is being polished away through surface abrasion during exposure. Whether the polished/brown artefacts from the buff layer ever had the grey patina in the first place, however, cannot be confirmed from these observations.

\subsubsection{Collection and Recording of Surface Artefacts from L0106/130}

The assemblage collected from 120 quadrants in L0106 during the 2015 and 2017 seasons numbers 2,431 artefacts (Table 3): 94 techno-typologically defined as ESA; 718 as MSA; 14 as LSA; and 1,605 as non-diagnostic. This is in addition to 98 artefacts collected by GPS waypoint before establishment of the grid (11 ESA, 43 MSA; 2 LSA and 42 nondiagnostic). Across L0130, 380 artefacts were recorded in the field from the 40 sampled quadrants. In broad terms, the assemblage comprises artefacts and manufacturing debris that can be assigned both to the ESA and MSA on typological and technological criteria, overwhelmingly made on the locally available raw material from naturally exfoliated basalt flakes or collected in the form of rolled cobbles, with some limited evidence of artefacts from a later period in the form of five pieces of chert, quartz and indurated shale. 


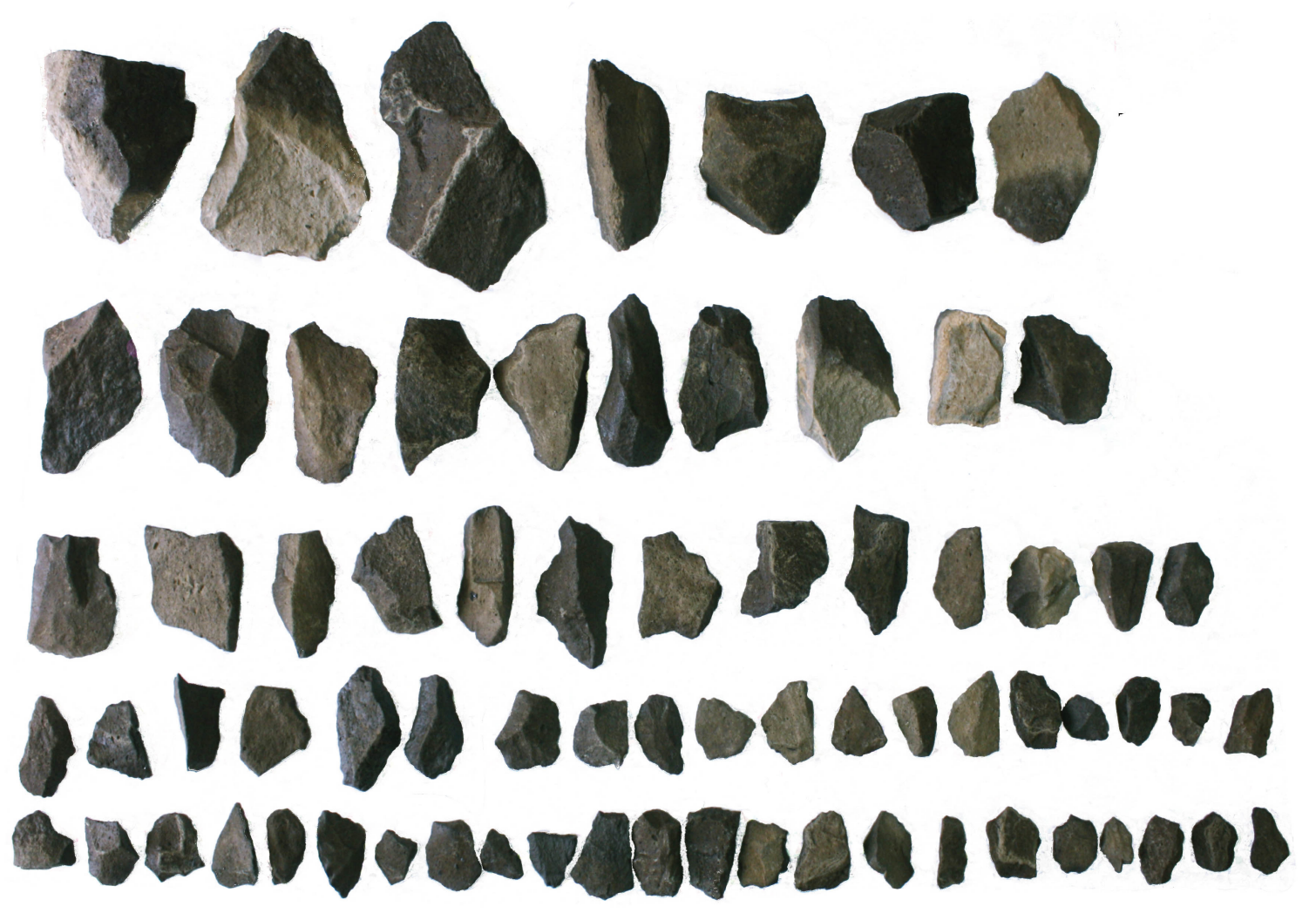

Figure 10. An example of a collected assemblage from quadrant 6Bz in Grid L0106 with examples of a range or working and patination. This particular assemblage contains a series of 72 flakes ranging from large cortical and semi-cortical pieces in the upper row produced as the basalt nodules are flaked for the first time, an example of a prepared-core (MSA) flake in the second row, and various flakes produced during the preparation phase of a prepared-core. The bottom two rows contain small flakes and shatter pieces. Photo: A. Sinclair.

Table 3: Total numbers of artefacts recorded from the Wadi Dabsa basin and within surveyed grid L0106/0130, by chronotypological classification.

\begin{tabular}{|l|l|l|l|l|l|}
\hline Location & ESA & MSA & LSA & Non-diagnostic & Total \\
\hline L0106 Non-Grid Waypoints & 11 & 43 & 2 & 42 & 98 \\
\hline L0106 Grid (Collected) & 94 & 718 & 14 & 1605 & 2431 \\
\hline L0130 Grid (Field Recorded) & 76 & 144 & 0 & 182 & 380 \\
\hline Test Pits & 1 & 8 & 1 & 51 & 61 \\
\hline Total Artefacts & $\mathbf{1 8 2}$ & $\mathbf{9 1 3}$ & $\mathbf{1 7}$ & $\mathbf{1 8 8 0}$ & $\mathbf{2 9 7 0}$ \\
\hline
\end{tabular}

The assemblage from Grid L0106 contains artefacts from all stages of lithic reduction including tested clasts, cortical and semi-cortical flakes, cores and core-preparation materials, retouched pieces, many shatter fragments, and some probable hammerstones attesting to the flaking of basalt at this location (Figure 10). There are more than 280 retouched pieces that 
include a range of classic Acheulean retouched forms (bifaces, cleavers, large cutting tools) from the ESA as well as a series of prepared cores and flakes dating to the MSA, indicating a range of activities that might have been undertaken at the site and, in certain cases, the preparation of armatures for use elsewhere. Finally, there are a small number of true blades and bladelets deriving from prismatic blade cores, of MSA age or possibly younger.

The assemblage recorded but not collected from L0130 is smaller in number than that recorded in L0106, and almost certainly missing the less visible pieces, due to the more rapid survey of the quadrants. Despite this, the range of technological pieces, as well as retouched pieces, suggests that the assemblage in this grid closely mirrors that from L0106 both in chronological periods and range of technological activity.

\section{Artefact Condition}

The variability in surface characteristics of the artefacts collected and recorded from the grids mirrored that observed in the test pits: most of the artefacts collected and observed in the 2015 and 2017 surveys were dark brown/polished, although flake scars were still clearly visible, whilst others were grey and sharp-edged; other artefacts exhibited both surface conditions on different faces (Figure 11). A small number of artefacts exhibiting this variation in surface characteristics were also observed during 2017 on the squares surveyed in 2015 (Rows 1-4), and from which all artefacts had been collected. Given that the areas of grey patina on these pieces are the same as that observed on the stratified material from the test pits, it is likely that these artefacts were originally contained within the artefact-bearing unit, but had become uncovered between 2015 and 2017, and their grey patinas partially polished away.

In Quadrant 5Jw, a basalt handaxe partially encased in tufa was found on the edge of a small rill that drains the NW corner of L0130 (Figure 12). While the find was a loose clast, and therefore removed from the geomorphological context in which it developed the tufa coating, it suggests that tufa deposition may have occurred after manufacture of at least some of the artefacts. Artefacts retrieved from the test pits, in contrast, stratigraphically overlie and therefore post-date the deposition of tufa at this location. 

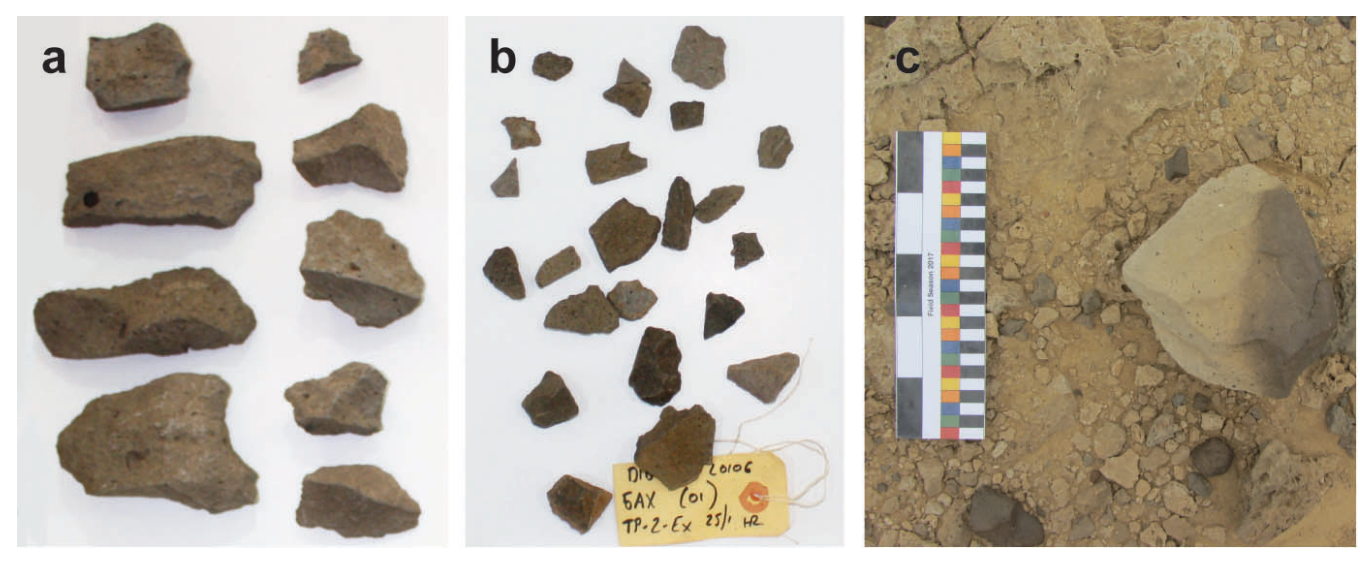

Figure 11: Artefacts from L0106 test pits showing differences in patina: a) grey layer; b) buff layer; c) a core with variable patina in 2017 lying on the surface of a grid square surveyed in 2015. Photos: $a-b)$ H. Robson, c) R. Inglis.
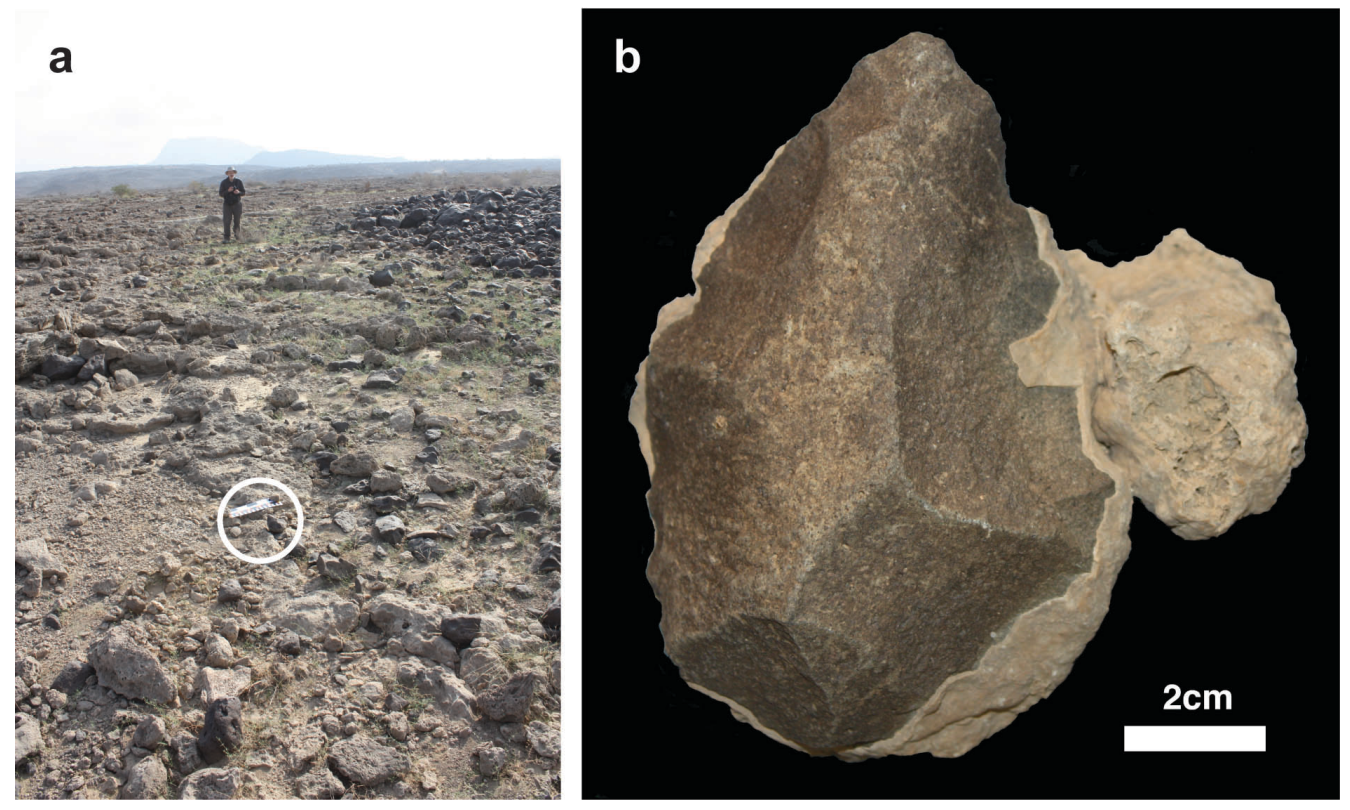

Figure 12: Handaxe encased in tufa a) on surface in Quadrant 5Jw of L0130 (circled; Photo: R. Inglis) and b) post-collection (photo: H. Robson).

\subsubsection{Spatial Distribution of Surface Artefacts Within L0106/L0130}

The mean number of artefacts per quadrant collected from the surface of L0106 is 20.33 $\left(0.81 \mathrm{artefacts} / \mathrm{m}^{2}\right)$, although a standard deviation of 23.50 indicates that there is considerable variability in artefact number across the grid, with the high numbers of recorded artefacts in $5 \mathrm{Cw}$ and 5Cy (132 and 145 respectively) skewing the mean (Figure 13a). There is an increase in artefact counts per quadrant towards the northeast edge of the grid (Figure 13a), on the flattest part of the Crest landform unit, and the landform units with the highest visibility surfaces (i.e., Crest and Upper Slope) have generally higher artefact counts per quadrant while 
the lowest artefact counts are found on the landform unit with the lowest visibility surface (Drainage). Testing of these models in the L0130 grid is not possible given the different survey technique, as well as the fact that the surveyed squares did not intersect the Crest landform unit in this grid. Beyond this broad scale patterning, there seems to be little relationship between number of artefacts and the percentage of bare tufa within a quadrant, although at the subquadrant scale, artefacts were more often observed on areas of sediment which had become trapped between tufa outcrops, rather than on the bare tufa itself.

a. Total Artefacts

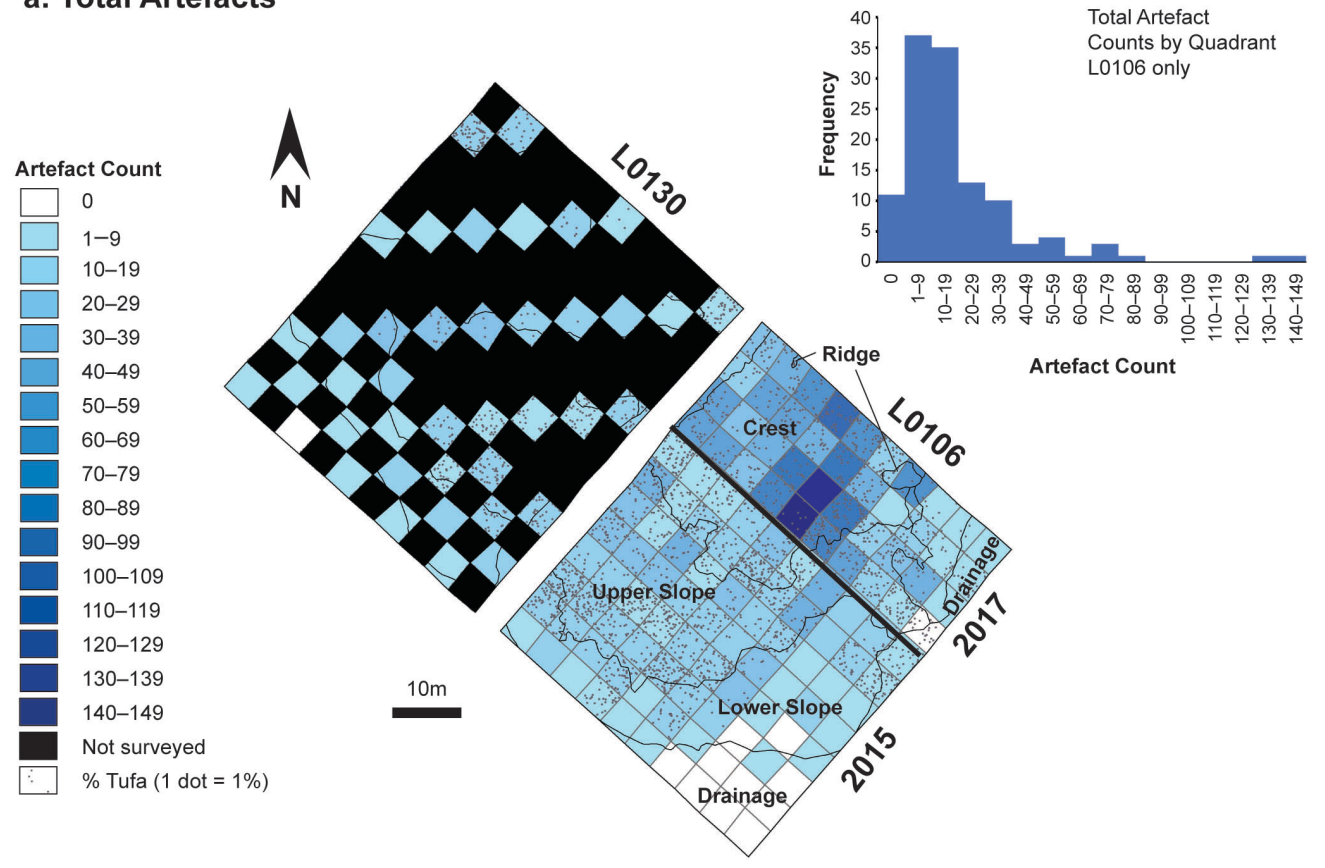

b. Artefacts by Chronotypology

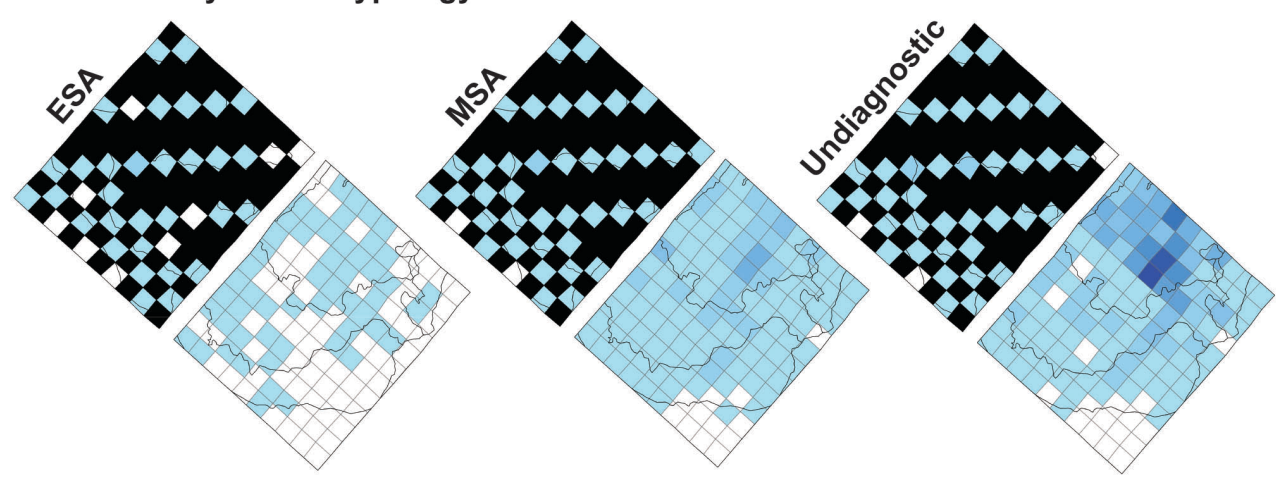

Figure 13: Distribution of artefact counts across Grid L0106 \&L0130: a) histogram of total artefact counts by quadrant (L0106 only), and distribution of total artefacts by quadrant square showing percent bare tufa and relationship to landform units; b) distribution of artefact counts by quadrant following division by techno-typological classification. 
Mapping artefacts according to identified chronotypology (ESA, MSA, or nondiagnostic) was carried out to attempt to separate phases of activity on the site (Figure 13b; the small number of LSA artefacts precluded meaningful mapping). The ESA artefacts are distributed largely evenly across the grid in low densities, whilst the patterning of the MSA artefacts across the grid is broadly consistent with that shown by the total assemblage. The ESA artefacts, however, comprise just 94 of the total of 2,431 artefacts collected from L0106, and average less than a single artefact per quadrant. The majority of the assemblage $(1,605$ artefacts, $66 \%$ ) cannot be typologically assigned to a chronological period.

To statistically test the apparent relationships between artefact counts and landforms, the expected and observed artefact counts of quadrants completely within one landform (a total of 62 quadrants) were tested using chi squared tests (Table 4), with the null hypothesis that artefact counts were unrelated to the landforms. In all cases (except for the LSA artefacts whose low number precluded testing), the $\mathrm{p}$ value was well below the significance value of 0.05 , indicating that the null hypothesis can be rejected, and that the observed relationships between artefact counts and landforms mapped above are significant.

Table 4: Expected and observed counts of artefacts on L0106 quadrants contained within a single landform $(n=62)$, and $\chi^{2}$ test statistics for artefact-landform relationships by chronotypological period.

\begin{tabular}{|c|c|c|c|c|c|c|c|}
\hline & & \multicolumn{4}{|c|}{ Landform Unit } & \multirow{4}{*}{$\chi^{2}$} & \multirow{4}{*}{$\mathbf{p}$} \\
\hline & & Crest & $\begin{array}{l}\text { Upper } \\
\text { Slope }\end{array}$ & Lower Slope & Drainage & & \\
\hline \multicolumn{2}{|c|}{$\begin{array}{l}\text { No. of Complete } \\
\text { Quadrants }\end{array}$} & 22 & 19 & 14 & 7 & & \\
\hline \multicolumn{6}{|c|}{ Artefact Counts } & & \\
\hline \multirow{2}{*}{$\begin{array}{c}\text { Total } \\
(n=1528)\end{array}$} & Observed & 1028 & 319 & 173 & 8 & \multirow{2}{*}{725.52} & \multirow{2}{*}{0.000000} \\
\hline & Expected & 542 & 468 & 345 & 173 & & \\
\hline \multirow{2}{*}{$\begin{array}{c}\text { ESA } \\
(n=62)\end{array}$} & Observed & 35 & 22 & 5 & 0 & \multirow{2}{*}{20.94} & \multirow[t]{2}{*}{0.000108} \\
\hline & Expected & 22 & 19 & 14 & 7 & & \\
\hline \multirow{2}{*}{$\begin{array}{c}\text { MSA } \\
(n=429)\end{array}$} & Observed & 254 & 130 & 44 & 1 & \multirow{2}{*}{143.37} & \multirow[t]{2}{*}{0.000000} \\
\hline & Expected & 152 & 131 & 97 & 48 & & \\
\hline \multirow{2}{*}{$\begin{array}{c}\text { Non- } \\
\text { diagnostic } \\
(\mathrm{n}=1028)\end{array}$} & Observed & 737 & 160 & 124 & 7 & \multirow[b]{2}{*}{608.98} & \multirow{2}{*}{0.000000} \\
\hline & Expected & 365 & 315 & 232 & 116 & & \\
\hline
\end{tabular}




\section{DISCUSSION}

\subsection{Geomorphology and Artefacts at L0106/L0130}

Investigation of the geomorphological context of artefacts recorded in Grids L0106/0130 suggests the manner in which the surface assemblage has developed across space and over time and continues to accumulate in the present. This has important implications for any interpretations that might wish to propose specific differentiation of hominin behaviours based on the local spatial patterning of the assemblage.

A comparison between the state of patination of the artefacts within sediments exposed in the test pits, and the artefacts collected on the surface, indicate that some of the artefacts recovered from the present day surface were previously contained within the grey sediment unit, and thus deposited following cessation of tufa deposition at this location and have been exposed by deflation. Moreover, the accumulation of a surface assemblage at L0106/130 may be ongoing as evidenced firstly by the observation in 2017 of artefacts lying on squares that had been fully collected in 2015, and secondly by the variable patina of these artefacts, suggesting that new artefacts had been uncovered. Whilst this deflation may have been predominantly low-energy aeolian winnowing, heavy rainfall in this region in 2016 may have caused sheetwash erosion of this unit, possibly primed by the 2015 survey disrupting the previously stable surface through trampling; a similar disruption was observed by one of the authors at semi-arid field sites in western New South Wales, Australia (Fanning et al., 2007; Fanning, Holdaway, Rhodes, \& Bryant, 2009). While the exposure of additional artefacts during this survey hiatus may go some way to accounting for the higher artefact counts observed in the 2017 squares (Rows 5 and 6), new artefacts on the 2015 rows were relatively few and could not alone have accounted for the observed increase between Rows 4 and 5 . Furthermore, patterns in artefact count by landform in Rows 5 and 6 mirror those in Rows 1-4.

Variations in artefact counts across landform types reflects the geomorphological processes acting on the distribution of the artefact assemblage (Figure 14): high artefact counts on the Crest landform appear to be linked to the predominantly low-energy deflation of the fine sediment of the grey, artefact bearing unit, that exposed artefacts to survey whilst still leaving large clasts and artefacts broadly in place, creating a high visibility 'pavement' of clasts and artefacts. The Upper Slope has equally good artefact visibility, but with a steeper topography that is more prone to erosion and downslope moment of material, perhaps reflected in the 
somewhat lower artefact counts in these quadrants. Finally, the Lower Slope and Drainage landforms mark a shift to a predominantly depositional environment that decreases the visibility of artefacts, evidenced by lower artefact counts.

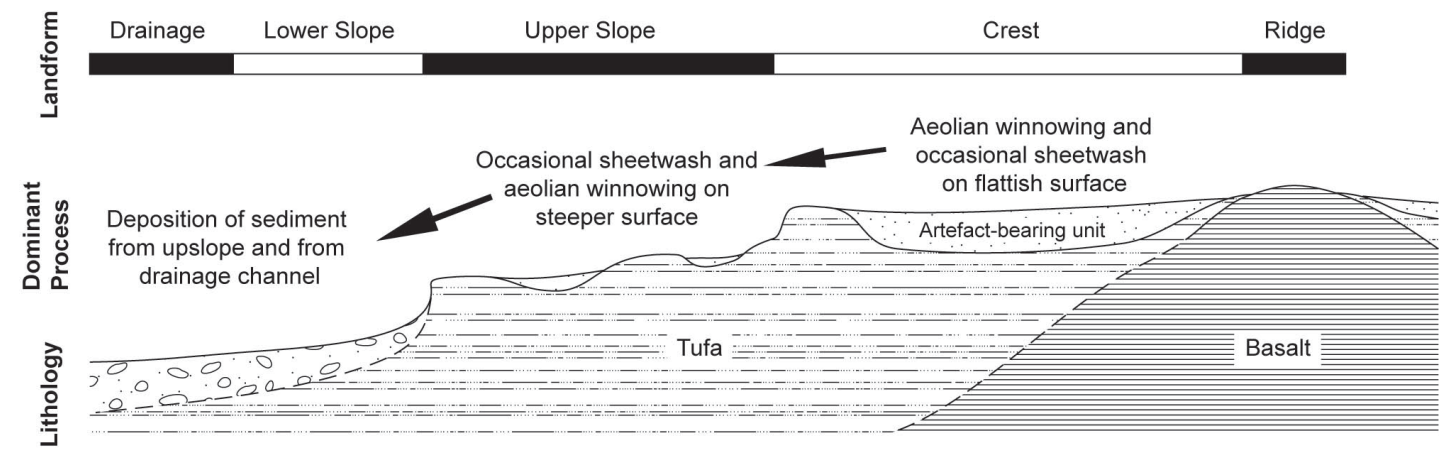

Figure 14: Schematic diagram of the geomorphological processes acting on the L0106/0130 grid are and their relationships to the mapped landforms and lithostratigraphy.

While the spatial distribution of the surface artefacts are largely consistent with geomorphological processes acting on the artefact-bearing unit overlying the tufa as described above, it should not be assumed that all the surface artefacts originated from this same unit. Grey-patinated artefacts mark an origin within the grey unit, and exposure of artefacts to wind erosion removes the patination. After some unknown time at the surface, it would be difficult to visually distinguish previously patinated (i.e., buried) artefacts from those that had never been patinated. Furthermore, the discovery of a tufa-encased handaxe suggests evidence for human activity and artefact deposition before, or contemporaneous with, tufa deposition. This is the inverse relationship to that of the artefacts contained or originating within the sediments overlying the tufa and strengthens the chronotypological assessment of the assemblage as possessing deep time depth, with periods of ESA and MSA activity at the location now deflated into a single surface assemblage, or palimpsest. Comparing distributions of the ESA and MSA artefacts identifiable to a chronotypological cultural period is problematic given the major variation in sample size between the ESA and MSA artefact assemblages, but the MSA artefact distribution (i.e. highest counts in the Crest landform), coupled with the recovery of diagnostic MSA artefacts from the test pits appears closely consistent with an origin of the MSA artefacts in the grey sediment. unit according to the above model.

In summary, the spatial patterning at L0106/0130 can mostly be explained by geomorphological controls acting on the preservation, exposure and visibility of an (MSA) artefact-bearing unit that is preserved primarily in the Crest unit. The null hypothesis that geomorphology, rather than behaviour, controls patterning at the grid scale cannot be rejected, 
precluding interpretation of spatial patterning of artefacts at this scale purely in behavioural terms. This is not to say, however, that the assemblage can yield no behavioural data. Refitting of flakes and cores from the site would further understanding of the integrity of the artefact assemblage, essential for assessing the constraints and potential for further lithic analyses at the locality (E. Foley, Spry, \& Stern, 2017). Already one refitted prepared core and flake has been identified, and a more extensive refitting of prepared flakes and cores is planned (Sinclair et al., In Press). A major challenge for this future analysis of the L0106/0130 material, therefore, will be determining whether separate periods of activity can be distinguished within the surface assemblage using evidence beyond spatial location alone.

\subsection{Surface Variability and Artefact Distribution in the Wadi Dabsa Basin}

The observed artefact distribution within the L0106/0130 grid appears to have been heavily influenced by the geomorphological conditions that control the preservation, exposure and visibility of artefacts. Therefore, therefore variability in surface conditions across the basin are likely similarly determining factors in artefact spatial patterning at the basin scale, a critical issue when considering whether L0106/130 marks a particular, persistently attractive location in the landscape.

At L0106/0130, the quadrants with the highest artefact counts were found on subdued topography covered by fine-grained, artefact-bearing sediments allowing the formation of lag deposits through winnowing of fine material by wind and water, (as well as sporadic highenergy surface sheet flow during rainstorms) by exposing artefacts and other clasts, but with insufficient energy to move them into areas of net sedimentation where they could be buried. Such deposits, sometimes referred to as deflationary desert pavements (Laity, 2011), are familiar to those working in Palaeolithic archaeology in the arid zone (e.g. Hill, 2000; Jones et al., 2011; Knight \& Zerboni, 2018). Similar surface conditions have been observed elsewhere in the Wadi Dabsa basin during exploratory transects, but often with only rare artefacts on their surfaces. Whilst this indicates that the large numbers of artefacts at L0106/0130 may indeed result from a concentration of hominin behaviour, this model would need systematic testing through further refinement of the sediment mapping in the basin.

One avenue for refining this mapping is the application of automatic classification described above. The analysis described in Section 4.2 identified differences in surface sedimentation, including across the artefact collection grids where the landforms mapped in the field broadly correspond to the distinctions made by the automatic classification. These 
broad classes, however, encompassed significant variations that, at the grid scale, were shown to affect artefact visibility: the Crest and the Upper Slope landforms were contained within Class Nine, whilst Class Ten included both the Lower Slope and Drainage landforms. This lack of resolution may result from the parameters inputted into the classification - of the ten defined classes, seven were automatically assigned to the variability on surfaces other than tufa - and future supervised classification of the tufa surface using high resolution multi-spectral satellite imagery and the groundtruthing observations above, combined with LiDAR DEM, may allow the finer resolution of surface condition. Given that the landform units control artefact patterning in the grid on the tens of metres scale, there may, however, be a limit to what can be defined through remote sensing, and what surface conditions must be logged in the field, once more demonstrating the need for assessment of geomorphological conditions at multiple, nested scales to fully understand the distribution of artefacts across the basin.

\subsection{Broad-Scale Landscape Stratigraphy, Evolution and Hominin Activity}

The landscape at Wadi Dabsa provided a major intersection of features often deemed attractive to hominin population, including abundant raw material sources, water that would have been essential to both hominins and the prey they hunted, and topographic complexity that would have allowed populations to observe, trap, and hunt animals within the basin. Yet, whilst some of these elements would have existed since the initiation of volcanism at this location, the presence of water is likely to have been episodic, responding to environmental changes; the topography that shaped its flow may also have varied through the emplacement of basaltic lava flows. To consider the Wadi Dabsa basin from the perspective of past homininlandscape interactions, we need to determine when these favourable conditions existed, and how and when they changed over time within the timeframe of potential occupation of the region (potentially the last $1.8 \mathrm{Ma}$ ).

The geomorphological framework developed above provides a relative stratigraphy of landscape development which will be tested and constrained by further analyses and chronometric dating of the sediments within which the archaeological material is situated. Firstly, the broad morphology of the basin, defined by basaltic flows, was likely established prior to tufa deposition - all field observations indicate tufa deposition post-dated basalt flow emplacement. It cannot be assumed, however, that no earlier phases of tufa deposition occurred in the basin floor that have been subsequently buried by later tufa deposition or overlapped by basalt flows. Indeed, the $>2 \mathrm{~m}$ depth of tufa exposed in a wadi the southern edge of the basin illustrates the potential depth and complexity of the tufa deposits. More detailed mapping and 
${ }^{238} \mathrm{U}-{ }^{230}$ Th dating of the range of tufa settings and facies will be required to further constrain periods of tufa deposition.

From the tufa forms, settings and macro-morphologies observed, it is clear that the morphology of the basin encouraged ponding of water and establishment of marshy areas that may have attracted prey and hominins to the basin. Water flowing from constrained channels into the wide basin would have lost energy, as well as potentially becoming dammed at the pinch point at the outflow channel at the western edge of the basin. Carbonate precipitation from calcium-carbonate rich water is encouraged by the presence of organic material: vegetation acts as a substrate for accumulation (Pedley, 1990) and algae aid removal of carbon dioxide from solution to encourage carbonate precipitation (Ford \& Pedley, 1996), whilst flowing water encourages turbulent carbon dioxide degassing, again encouraging carbonate precipitation (Ford \& Pedley, 1996). Drivers behind periods of tufa formation in this now semiarid to arid basin were climatic, corresponding to periods of increased rainfall and reduced evapotranspiration as documented elsewhere in Saudi Arabia (Kabesh and Abdel-Motelib, 2014), western Namibia (Brook, 1999), north western Spain (Pena, Sancho \& Lozano, 2000), Croatia (Horvatincic, Calic, \& Geyh, 2000), Israel (Livnat and Kronfeld, 1985); the Grand Canyon USA, (Szabo, 1990), Egypt (Smith, Giegengack, \& Schwarcz, 2004; Smith et al., 2004), and Namibia (Stone, Viles, Thomas \& Van Calsteren, 2010). From existing speleothem chronologies on the Arabian Peninsula it is likely that this occurred in (but may not have been limited to) interglacial periods (Parker, 2009; Preusser, 2009; Fleitmann et al., 2011; Jennings et al., 2015;). Disentanglement of the drivers of water flow in the basin will be aided by further analysis of tufa morphology and fabric from macro-morphology to the detailed description of micro-morphology of thin sections using microscopy, in order to understand the depositional environments. In addition, stable isotopic analysis of the carbonate will to provide insights into the moisture sources and temperatures during deposition (Andrews, Pedley, \& Dennis, 2000; Gandin \& Capezzuoli, 2008).

At some point, the environment that had promoted large-scale tufa deposition ceased to exist within the basin, and incision and weathering of the tufa began. Incision may have been driven by the changing base-level of fluvial erosion, linked to falls in sea level, as well as changing precipitation patterns resulting in more flashy episodes of high energy flow that would have eroded the tufa (cf in the Naukluft Mountains, Namibia, Viles, Taylor, Nicoll, \& Neumann, 2007), or a combination of the both. 
Situating the artefacts observed at L0160/0130 within the landscape stratigraphy is possible through the relationships between the artefacts and tufa observed on the grids, and this stratigraphy will be chronologically constrained by the ongoing programme of ${ }^{238} \mathrm{U}_{-}{ }^{230} \mathrm{Th}$ and ${ }^{39} \mathrm{Ar} /{ }^{40} \mathrm{Ar}$ dating. The tufa-encased handaxe suggests that hominins were present within the basin, discarding artefacts before, or contemporary with, at least one phase of tufa formation. By contrast, the artefacts overlying tufa in the grids indicate activity also took place after tufa deposition ceased. Chronometric dating of the tufa, and the basalt outcrops from which the artefacts may have been manufactured, will constrain this activity within the wider chronology of the occupation of the Arabian Peninsula by providing maximum and minimum ages for the tufa-encased handaxe, and a maximum age for the deposition of the artefacts in the grey unit.

Hominin activity cannot, at present, be associated directly with a specific environment. It is likely that activity would have taken place during periods in which water was flowing at Wadi Dabsa, but it is also possible that activity could have taken place both before and after tufa deposition in different environmental conditions, perhaps during periods of reduced, but still present, flow. The complexity of the tufa deposits and degrees of weathering observed in the basin means that it is very possible that there were multiple phases of tufa deposition in different areas of the basin, controlled by climatic fluctuations as well as topographic changes such as the damming and rerouting of watercourses by vegetation and development of tufa barrages, all of which need to be the focus of future survey and analysis.

\section{CONCLUSIONS}

The geoarchaeological investigations at Wadi Dabsa reported here have demonstrated the fundamental relationship between the visibility of artefacts to present-day survey and their geomorphological setting, relationships which are integral to the interpretation of this locality and all surface records with regards to hominin landscape use.

The 2,970 artefacts observed at L0106/0130 make this the largest Palaeolithic assemblage recorded to date in southwestern Saudi Arabia. The geomorphological observations recorded above indicate that this assemblage is not the product of a single period of activity at the site, but rather a palimpsest of artefacts deposited before and after, and potentially during, phases of tufa deposition at the locality. This extended time depth is also indicated by the techno-typological characteristics of the artefacts within the assemblage. As with all surface assemblages, this time depth must be considered when framing its analysis and interpretation. Patterning of the artefacts at the grid scale provides a powerful demonstration 
of the interaction between geomorphological processes and the degree to which artefacts are preserved, exposed and visible at a location, and constrains the research questions that can be applied at each scale. Whilst no similarly dense accumulations of artefacts have been observed elsewhere during the exploratory survey of the basin, only the detailed mapping of the tufa surface, and systematic survey of similar geomorphological settings, can determine the potential for this assemblage to mark a particular, persistent focus of hominin activity within the basin.

Investigation of the landscape at the basin scale has allowed the construction of a wider landscape context for the archaeology that will aid future interpretations of activity in the basin. Whilst surface assemblages are often seen to lack chronological control, the stratigraphic relationships between artefacts and tufa, both underlying and encasing them, observed at Wadi Dabsa allow us to start to link these artefacts within a relative stratigraphy that can be constrained by absolute dating of the tufa and basalt flows. This will allow consideration of the timing of the evolution of the landscape, any responses to regional and global environmental change, and the timing and conditions of hominin activity in the basin over time, and how it may have changed with the landscape.

The geomorphological framework presented in this paper provides the fundamental framework for the understanding of this important locality and its artefact assemblage, through laying out the dynamic processes behind the evolution of the Wadi Dabsa landscape, considering the changing opportunities within the basin for past hominin groups, as well as the ways in which geomorphological approaches have shaped, and will continue to, shape the distribution of the observed artefacts, and, by extension, our interpretations of the Palaeolithic occupation of the Red Sea coastal region.

\section{ACKNOWLEDGEMENTS}

We thank HRH Prince Sultan bin Salman bin Abdul Aziz, President of the Saudi Commission for Tourism and National Heritage (SCTH), KSA, Dr Hussein Abu Alhassan, Vice-President, and Dr Abdullah Al Zahrani, Director General, for granting fieldwork permission, as well as their interest in and support of our work in Saudi Arabia. Grateful thanks are also extended to: Dr Dhaifullah Al Othaibi, SCTH; Mr Saeed Al Karni, Director of Antiquities in Asir; the staff of the SCTH offices in Abha and at the National Museum, Riyadh; Dr Andrew Shuttleworth, Dr Frederick Foulds, Dr Harry Robson, Dr Saud Al Ghamdi, and all team members of the 2015 and 2017 Saudi-UK survey seasons at Wadi Dabsa; and Dr Helen 
Goodchild, University of York. AMA also thanks the Research Centre at the College of Tourism and Archaeology, King Saud University, for their support.

Work at Wadi Dabsa was carried out by the SURFACE project funded by the European Union's Horizon 2020 research and innovation programme under the Marie Skłodowska-Curie grant agreement No. 660343, 'Human-Landscape-Interactions and Global Dispersals: The SURFACE Record of Palaeolithic Arabia' and builds on survey by the DISPERSE project, funded by European Research Council Advanced Grant 269586, under the 'Ideas' Specific Programme of FP7. For generous funding for the fieldwork we thank: the Gerald Averay Wainwright Fund for Near Eastern Archaeology at the University of Oxford (2015, 2017); the British Academy, Albert Reckitt Fund (2017); the British Foundation for the Study of Arabia (2017); and the Department of Archaeology Research Fund, University of York (2015).

\section{REFERENCES}

\section{References}

Andrews, J.E., Pedley, H.M., \& Dennis, P.F. (2000). Palaeoenvironmental records in Holocene spanish tufas: A stable isotope approach in search of reliable climatic archives. Sedimentology, 47(961-978).

Armitage, S.J., Jasim, S.A., Marks, A.E., Parker, A.G., Usik, V.I., \& Uerpmann, H.-P. (2011). The Southern Route "Out of Africa": evidence for an early expansion of modern humans into Arabia. Science, 331, 453-456.

Bailey, G.N. (2007). Time perspectives, palimpsests and the archaeology of time. Journal of Anthropological Archaeology, 26, 198-223.

Bailey, G.N. (2009). The Red Sea, Coastal Landscapes, and Hominin Dispersals. In M.D. Petraglia \& J.I. Rose (Eds.), The Evolution of Human Populations in Arabia (pp. 1537). Amsterdam: Springer.

Bailey, G.N., Devès, M.H., Inglis, R.H., Meredith-Williams, M.G., Momber, G., Sakellariou, D., et al. (2015). Blue Arabia: Palaeolithic and underwater survey in SW Saudi Arabia and the role of coasts in Pleistocene dispersals. Quaternary International, 382, 42-57.

Bailey, G.N., Flemming, N.C., King, G.C.P., Lambeck, K., Momber, G., Moran, L.J., et al. (2007). Coastlines, Submerged Landscapes, and Human Evolution: The Red Sea Basin and the Farasan Islands. The Journal of Island and Coastal Archaeology, 2(2), 127-160.

Barham, L., \& Mitchell, P. (2008). The First Africans. Cambridge: Cambridge University Press.

Bosworth, W., \& Stockli, D. (2016). Early magmatism in the greater Red Sea rift: timing and significance. Canadian Journal of Earth Sciences, 53(11), 1158-1176.

Breeze, P.S., Groucutt, H.S., Drake, N.A., White, T.S., Jennings, R.P., \& Petraglia, M.D. (2016). Palaeohydrological corridors for hominin dispersals in the Middle East $\sim 250$ 70,000 years ago. Quaternary Science Reviews, 144, 155-185.

Brook, G.A., Marias, E., \& Cowart, J.B. (1999). Evidence of wetter and drier condiitons in Namibia from tufas and submerged speleothems. Cimbebasia, 15(29-39).

Coleman, R.G., Gregory, R.T., \& Brown , G.F. (1983). Cenozoic volcanic rocks of Saudi Arabia. United States Geological Survey. 
Dabbagh, A., Emmermann, R., Hötzl, H., Jado, A.R., Lippolt, H.J., Kollman, W., et al. (1984). The development of Tihamat Asir during the Quaternary. In A.R. Jado \& J.G. Zötl (Eds.), Quaternary Period in Saudi Arabia Volume 2: Sedimentological, Hydrogeological, Hydrochemical, Geomorphological, Geochronological and Climatological Investigations in Western Saudi Arabia (pp. 150-173). Vienna: Springer-Verlag.

Davies, B., Holdaway, S.J., \& Fanning, P.C. (2016). Modelling the palimpsest: an exploratory agent-based model of surface archaeological deposit formation in a fluvial arid landscape. The Holocene, 26(3), 450-463.

Davies, B., Holdaway, S.J., \& Fanning, P.C. (In Press). Modelling relationships between space, movement and lithic geometric attributes. American Antiquity.

Dearing, J., Dann, R.J.L., Hay, K., Lees, J.A., Loveland, P.J., Maher, B.A., et al. (1996). Frequency-dependent susceptibility measurements of environmental materials. Geophysical Journal International, 124, 228-240.

Delagnes, A., Crassard, R., Bertran, P., \& Sitzia, L. (2013). Cultural and human dynamics in southern Arabia at the end of the Middle Paleolithic. Quaternary International, 300, 234-243.

Delagnes, A., Tribolo, C., Bertran, P., Brenet, M., Crassard, R., Jaubert, J., et al. (2012). Inland human settlement in southern Arabia 55,000 years ago. New evidence from the Wadi Surdud Middle Paleolithic site complex, western Yemen. Journal of Human Evolution, 63, 452-474.

Devès, M., Sturdy, D., Godet, N., King, G.C.P., \& Bailey, G.N. (2014). Hominin reactions to herbivore distribution in the Lower Palaeolithic of the Southern Levant. Quaternary Science Reviews, 96, 140-160.

Drake, N.A., Blench, R.M., Armitage, S.J., Bristow, C.S., \& White, K.H. (2011). Ancient watercourses and biogeography of the Sahara explain the peopling of the desert. Proceedings of the National Academy of Sciences USA, 108(2), 458-462.

Drake, N.A., Breeze, P., \& Parker, A. (2013). Palaeoclimate in the Saharan and Arabian Deserts during the Middle Palaeolithic and the potential for hominin dispersals. Quaternary International, 300, 48-61.

Fanning, P.C., \& Holdaway, S.J. (2004). Artifact Visibility at Open Sites in Western New South Wales, Australia. Journal of Field Archaeology, 29, 255-271.

Fanning, P.C., Holdaway, S.J., \& Rhodes, E. (2007). A geomorphic framework for understanding the surface archaeological record in arid environments. Geodinimica Acta, 20(4), 275-286.

Fanning, P.C., Holdaway, S.J., Rhodes, E.J., \& Bryant, T.G. (2009). The surface archaeological record in arid Australia: Geomorphic controls on preservation, exposure, and visibility. Geoarchaeology, 24(2), 121-146.

Ferring, C.R., Orms, O., Agusti, J., Berna, F., Nioradze, M., Sheila, T., Tappen, M., Vekua, A., Zhvania, D., \& Lordkipanidze, D. 2012. Earliest human occupations at Dmanisi (Georgian Caucasus) dated to 1.85-1.78 Ma. Proceedings of the National Academy of Sciences USA, 108, 10432-10436.

Finlayson, C. (2013). The Water Optimisation Hypothesis and the human occupation of the mid-latitude belt in the Pleistocene. Quaternary International, 300, 22-31.

Fleitmann, D., Burns, S.J., Pekala, M., Mangini, A., Al-Subbary, A., Al-Aowah, M., et al. (2011). Holocene and Pleistocene pluvial periods in Yemen, southern Arabia. Quaternary Science Reviews, 30(7-8), 783-787.

Foley, E., Spry, C., \& Stern, N. (2017). Establishing the integrity and stratigraphic origin of stone artefact scatters on the surface of the Lake Mungo lunette in south-eastern Australia. Journal of Archaeological Science: Reports, 13, 547-557. 
Foley, R.A., \& Lahr, M.M. (1997). Mode 3 technologies and the evolution of modern humans. Cambridge Archaeological Journal, 7(1), 3-36.

Foley, R.A., \& Lahr, M.M. (2015). Lithic landscapes: early human impact from stone tool production on the central Saharan environment. PLoS One, 10(3), e0116482.

Ford, T.D., \& Pedley, H.M. (1996). A review of tufa and travertine deposits of the world. . Earth Science Reviews 41, 41, 117-175.

Foulds, F., Shuttleworth, A., Sinclair, A., Inglis, R., Alsharekh, A., Al Ghamdi, S., et al. (2017). A large handaxe from Wadi Dabsa and early hominin adaptations within the Arabian Peninsula. Antiquity, 91(360), 1421-1434.

Gandin, A., \& Capezzuoli, E. (2008). Travertine versus calcaerous tufa: distinctive petrologic features and stable isotopes signatures. . Italian Journal of Quaternary Sciences, 21(1B), 125-136.

Garcea, E.A.A. (2012). Successes and failures of human dispersals from North Africa. Quaternary International, 270, 110-128.

Garcea, E.A.A. (2016). Dispersals Out of Africa and Back to Africa: Modern origins in North Africa. Quaternary International, 408, 79-89.

Groucutt, H.S., Petraglia, M.D., Bailey, G.N., Scerri, E.M., Parton, A., Clark-Balzan, L., et al. (2015). Rethinking the dispersal of Homo sapiens out of Africa. Evolutionary Anthropology, 24, 149-164.

Groucutt, H.S., Grun, R., Zalmout, I.A.S., Drake, N.A., Armitage, S.J., Candy, I., ClarkWilson, R., Louys, J., Breeze, P.S., Duval, M., Buck, L.T., Kivell, T.L., Pomeroy, E., Stephens, N.B., Stock, J.T., Stewart, M., Price, G.J., Kinsley, L., Sung, W.W., Alsharekh, A., Al-Omari, A., Zahir, M., Memesh, A.M., Abdulshakoor, A.J., AlMasari, A.M., Bahameem, A.A., Al Murayyi, K.M.S., Zahrani, B., Scerri, E.L.M. \& Petraglia, M.D. 2018. Homo sapiens in Arabia by 85,000 years ago. Nature Ecology and Evolution, 2, 800-809.

Hill, C.L. (2000). Geologic Contexts of the Acheulian (Middle Pleistocene) in the Eastern Sahara. Geoarchaeology, 16(1), 65-94.

Holdaway, S.J., \& Douglass, M. (2012). A Twenty-First Century Archaeology of Stone Artifacts. Journal of Archaeological Method and Theory, 19(1), 101-131.

Holdaway, S.J., Douglass, M., \& Fanning, P.C. (2012). Landscape Scale and Human Mobility: Geoarchaeological Evidence from Rutherfords Creek, New South Wales, Australia. In S.J. Kluving \& E.B. Guttmann-Bond (Eds.), Landscape archaeology between art and science : from a multi- to an interdisciplinary approach (pp. 279294). Amsterdam: Amsterdam University Press.

Holdaway, S.J., \& Fanning, P.C. (2008). Developing a Landscape History as Part of a Survey Strategy: A Critique of Current Settlement System Approaches based on Case Studies from Western New South Wales, Australia. Journal of Archaeological Method and Theory, 15(2), 167-189.

Holdaway, S.J., \& Fanning, P.C. (2014). Geoarchaeology of Aboriginal Landscape Use in Semi-arid Australia. Melbourne: CSIRP Publishing.

Holdaway, S.J., King, G.C.P., Douglass, M.J., \& Fanning, P.C. (2015). Human-environment interactions at regional scales: the complex topography hypothesis applied to surface archaeological records in Australia and North America. Archaeology in Oceania, 50, 57-68.

Horvatincic, N., Calic, R., \& Geyh, M.A. (2000). Interglacial growth of tufa in Croatia. Quaternary Research, 53, 185-185.

Inglis, R.H., Bosworth, W., Bailey, G.N., \& Rasul, N. (In press). Investigating the Palaeoshorelines and Coastal Archaeology of the Southern Red Sea. In N. Rasul \& I. 
Stewart (Eds.), Geological Setting, Palaeoenvironment and Archaeology of the Red Sea. Amsterdam: Springer.

Inglis, R.H., Foulds, F., Shuttleworth, A., Alsharekh, A.M., Al Ghamdi, S., Sinclair, A.G., et al. (2015). 'The Palaeolithic Occupation of the Harrat Al Birk' Preliminary Report on the 2015 Fieldwork in Asir Province, Southwest Saudi Arabia. University of York/Saudi Commission for Tourism and Antiquities.

Inglis, R.H., Sinclair, A., Shuttleworth, A., Alsharekh, A., Al Ghamdi, S., Devès, M., et al. (2014). Investigating the Palaeolithic Landscapes and Archaeology of the Jizan and Asir Regions, Southwest Saudi Arabia. Proceedings of the Seminar for Arabian Studies, 44, 193-212.

Inglis, R.H., Sinclair, A.G., Alsharekh, A.M., Barfod, D.N., Chang, M., Fanning, P.C., et al. (2017). Preliminary Report on UK-Saudi 2017 Fieldwork At Wadi Dabsa, Asir Province, Saudi Arabia Saudi Commission for Tourism and National Heritage.

Ingraham, M.L., Johnson, T.D., Rihani, B., \& Shatla, I. (1981). Saudi Arabia Comprehensive Survey Program: Preliminary report on a reconnaissance survey of the Northwestern Province (with a note on a brief survey of the Northern province). Atlal, 5, 59-84.

Jennings, R.P., Shipton, C., Breeze, P., Cuthbertson, P., Bernal, M.A., Wedage, W.M.C.O., et al. (2015). Multi-scale Acheulean landscape survey in the Arabian Desert. Quaternary International, 382, 58-81.

Jennings, R.P., Singarayer, J., Stone, E.J., Krebs-Kanzow, U., Khon, V., Nisancioglu, K.H., et al. (2015). The greening of Arabia: Multiple opportunities for human occupation of the Arabian Peninsula during the Late Pleistocene inferred from an ensemble of climate model simulations. Quaternary International, 382, 181-199.

Jones, S., Farr, L., Barton, H., Drake, N., White, K., \& Barker, G. (2011). Geoarchaeological patterns in the pre-deset and desert ecozones of northern Cyrenaica. Libyan Studies, $42,11-20$.

Kabesh, M.M.L., \& Abdel-Motelib, A. (2014). Quaternary tufa profiles, Jabal Farasan, Wadi Qedid area, southern Saudi Arabia. Geopolitics, History and International Relations, 6(1), 146-159.

King, G.C.P., \& Bailey, G.N. (2006). Tectonics and human evolution. Antiquity, 80, 265286.

Knight, J., \& Zerboni, A. (2018). Formation of desert pavements and the interpretation of lithic-strewn landscapes of the central Sahara. Journal of Arid Environments. 153, 39-51.

Kübler, S., King, G.C.P., Devès, M.H., Inglis, R.H., \& Bailey, G.N. (In press). Tectonic geomorphology and soil edaphics as controls on animal migrations and human dispersal patterns. . In N. Rasul \& I. Stewart (Eds.), Geological Setting, Palaeoenvironment and Archaeology of the Red Sea. Amsterdam: Springer.

Kubler, S., Owenga, P., Reynolds, S.C., Rucina, S.M., \& King, G.C. (2015). Animal movements in the Kenya Rift and evidence for the earliest ambush hunting by hominins. Sci Rep, 5, 14011.

Laity, J.E. (2011). Pavements and stone mantles In D.S.G. Thomas (Ed.), Arid Zone Geomorphology (3rd ed., pp. 181-229). London: Wiley.

Lambeck, K., Purcell, A., Flemming, N.C., Vita-Finzi, C., Alsharekh, A.M., \& Bailey, G.N. (2011). Sea level and shoreline reconstructions for the Red Sea: isostatic and tectonic considerations and implications for hominin migration out of Africa. Quaternary Science Reviews, 30(25-26), 3542-3574.

Livnat, A., \& Kronfeld, J. (1985). Palaeoclimatic implciations of U-series date for lake sediments and travertines in the Arava Rift Valley, Israel. Quaternary Research, 24, $164-172$. 
Parker, A.G. (2009). Pleistocene Climate Change in Arabia: Developing a Framework for Hominin Dispersal over the Last 350 ka. In M.D. Petraglia \& J.I. Rose (Eds.), The Evolution of Human Populations in Arabia (pp. 39-49): Springer.

Pedley, H.M. (1990). Classification and environmental models of cool freshwater tufas. . Sedimentary Geology, 68, 143-154.

Pena, J.L., Sancho, C., \& Lozano, M.V . (2000). Climatic and tectonic significance of Late Pleistocene and Holocene tufa deposits in the Milares River canyon, eastern Iberian Range, Northwest Spain. . Earth Surface Processes and Landforms, 25, 1403-1417.

Petraglia, M.D. (2003). The Lower Palaeolithic of Arabian Peninsula: occupations, adaptations, and dispersals. Journal of World Prehistory, 17(2), 141-179.

Petraglia, M.D., \& Alsharekh, A. (2003). The Middle Palaeolithic of Arabia: implications for modern human origins, behaviour and dispersals. Antiquity, 77, 671-684.

Petraglia, M.D., Haslam, M., Fuller, D.Q., Boivin, N., \& Clarkson, C. (2010). Out of Africa: new hypotheses and evidence for the dispersal of Homo sapiens along the Indian Ocean rim. Ann Hum Biol, 37(3), 288-311.

Potts, D., Mughannum, A.S., Frye, J., \& Sanders, D. (1978). Comprehensive Archaeological Survey Program: Preliminary Report on the Second Phase of the Eastern Province Survey 1397/1977. Atlal, 2, 7-27.

Preusser, F. (2009). Chronology of the impact of Quaternary climate change on continental environments in the Arabian Peninsula. Comptes Rendus Geoscience, 341(8-9), 621632.

Rose, J.I. (2007). The role of the Saharo-Arabian arid belt in the modern human expansion. In From the Mediterranean basin to the Portugese Atlantic shore: Papers in Honor of Anthony Marks (pp. 57-67). Faro: Universidade do Algarve.

Rose, J.I., \& Petraglia, M.D. (2009). Tracking the Origin and Evolution of Human Populations in Arabia. In M.D. Petraglia \& J.I. Rose (Eds.), The Evolution of Human Populations in Arabia (pp. 1-12). Amsterdam: Springer.

Rose, J.I., Usik, V.I., Marks, A.E., Hilbert, Y., H, Galletti, C.S., Parton, A., et al. (2011). The Nubian Complex of Dhofar, Oman: An African Middle Stone Age Industry in Southern Arabia. PLoS One, 6(11), 1-22.

Rosenberg, T.M., Preusser, F., Blechschmidt, I., Fleitmann, D., Jagher, R., \& Matter, A. (2012). Late Pleistocene palaeolake in the interior of Oman: a potential key area for the dispersal of anatomically modern humans out-of-Africa? Journal of Quaternary Science, 27(1), 13-16.

Sinclair, A., Inglis, R., Shuttleworth, A., Foulds, F., Bailey, G.N., \& Alsharekh, A. (In Press). Landscape Archaeology, Palaeolithic Survey and Coastal Change along the Southern Red Sea of Saudi Arabia. In N. Rasul \& I.S. Stewart (Eds.), Geological Setting, Palaeoenvironment and Archaeology of the Red Sea. Amsterdam: Springer.

Smith, J.R., Giegengack, R., \& Schwarcz, H.P. (2004). Constraints on Pleistocene pluvial climates through stable-isotope analysis of fossil-spring tufas and assocaited gastropods, Karga Oasis, Egypt. Palaeogeography, Palaeoclimatology, Palaeoecology 206, 157-175.

Smith, J.R., Gigengack, R., Schwarcz, H.P., McDonald, M.M.A., Kleindienst, M.R., Hawkins, A.L., et al. (2004). A reconstruction of Quaternary pluvial environments and human occupations using stratigraphy and geochronology of fossil-spring tufas, Kharga Oasis, Egypt. Geoarchaeology, 19, 407-439.

Stern, N. (1994). The implications of time-averaging for reconstructing the land-use patterns of early tool-using hominids. J Hum Evol, 27, 89-105.

Stern, N. (2008). Time Averaging and the Structure of Late Pleistocene Archaeological Deposits in Southwest Tasmania. In S.J. Holdaway \& L. Wandsnider (Eds.), Time in 
Archaeology: Time Perspectivism Revisited (pp. 134-178). Salt Lake City: University of Utah Press.

Stone, A.E.C., Viles, H.A., Thomas, L., \& Van Calsteren, P. (2010). Can ${ }^{234}{ }^{2}{ }^{230}$ Th dating be used to date large semi-arid tufas? Challenges from a study in the Naukluft Mountains, Namibia. Journal of Quaternary Science, 25(8), 1360-1372.

Szabo, B.J. (1990). Ages of travertine depoists in eastern Grand Canyon National Park, Arizona. . Quaternary Research, 34, 24-32.

van Peer, P., \& Vermeersch, P.M. (2007). The place of Northeast Africa in the early history of modern humans: new data and interpretations on the Middle Stone Age. In P. Mellars, K. Boyle, O. Bar-Yosef \& C. Stringer (Eds.), Rethinking the Human Revolution (pp. 187-198). Cambridge: McDonald Institute.

Viles, H.A., Taylor, M.P., Nicoll, K., \& Neumann, S. (2007). Facies evidence of hydroclimatic regime shifts in tufa depositional sequences from the arid Naukluft Mountains, Namibia. Sedimentary Geology, 195(1-2), 39-53.

Vincent, P. (2008). Saudi Arabia: An Environmental Overview. Leiden: Taylor and Francis.

Winder, I.C., Bailey, G.N., Devès, M., King, G.C.P., Inglis, R.H., \& Meredith-Williams, M.G. (2015). Dynamic landscapes and complex topography as agents in human evolution: the dispersals of the genus Homo. Journal of Human Evolution, 87, 48-65.

Zarins, J., Ibrahim, I., Potts, D.T., \& Edens, C.M. (1979). Comprehensive Archaeological Survey Program: preliminary report on the survey of the Central Province 1978. Atlal, 3, 9-42.

Zarins, J., Murad, A., \& Al-Yaish, K. (1981). The Second Preliminary Report on the Southwestern Province. Atlal, 5, 9-42.

Zarins, J., Rahbini, A.-A., \& Kamal, M. (1982). Comprehensive Archaeological Survey Program - preliminary report on the archaeological survey of the Riyadh Area. Atlal, 6, 25-38.

Zarins, J., Whalen, N.M., Ibrahim, I., Morad, A., \& Khan, M. (1980). Comprehensive Archaeological Survey Program: preliminary report on the Central Southwestern Provinces survey. Atlal, 4, 9-117. 